Article

\title{
Synthesis and Antiplasmodial Activity of Novel Fosmidomycin Derivatives and Conjugates with Artemisinin and Aminochloroquinoline
}

\author{
Despina Palla ${ }^{1}$, Antonia I. Antoniou ${ }^{1}$, Michel Baltas ${ }^{2,3}$, Christophe Menendez ${ }^{2,3}$, \\ Philippe Grellier ${ }^{4}\left[{ }^{(}\right.$, Elisabeth Mouray ${ }^{4}$ and Constantinos M. Athanassopoulos ${ }^{1, *(1)}$ \\ 1 Synthetic Organic Chemistry Laboratory, Department of Chemistry, University of Patras, \\ GR-26504 Patras, Greece; despina.pal.5@gmail.com (D.P.); tonadoniou@upatras.gr (A.I.A.) \\ 2 LSPCMIB, UMR-CNRS 5068, Université Paul Sabatier-Toulouse III, CEDEX 9, 31062 Toulouse, France; \\ baltas@chimie.ups-tlse.fr or michel.baltas@lcc-toulouse.fr (M.B.); menendez@chimie.ups-tlse.fr (C.M.) \\ 3 CNRS, LCC (Laboratoire de Chimie, de Coordination), Université de Tolouse, UPS, INPT, \\ 205 Route de Narbonne, BP 44099, CEDEX 4 F-31077 Toulouse, France \\ 4 MCAM, UMR 7245, Muséum National d'Histoire Naturelle, CNRS, CP52, 63 rue Buffon, 75005 Paris, France; \\ grellier@mnhn.fr (P.G.); mouray@mnhn.fr (E.M.) \\ * Correspondence: kath@chemistry.upatras.gr; Tel.: +30-2610-997909
}

Academic Editors: Halina Ekiert and Agnieszka Szopa

Received: 26 September 2020; Accepted: 16 October 2020; Published: 21 October 2020

\begin{abstract}
Malaria, despite many efforts, remains among the most problematic infectious diseases worldwide, mainly due to the development of drug resistance by Plasmodium falciparum. The antibiotic fosmidomycin (FSM) is also known for its antimalarial activity by targeting the non-mevalonate isoprenoid synthesis pathway, which is essential for the malaria parasites but is absent in mammalians. In this study, we synthesized and evaluated against the chloroquine-resistant $P$. falciparum FcB1/Colombia strain, a series of FSM analogs, derivatives, and conjugates with other antimalarial agents, such as artemisinin (ART) and aminochloroquinoline (ACQ). The biological evaluation revealed four new compounds with higher antimalarial activity than FSM: two FSM-ACQ derivatives and two FSM-ART conjugates, with 3.5-5.4 and 41.5-23.1 times more potent activities than FSM, respectively.
\end{abstract}

Keywords: fosmidomycin; chloroquine; artemisinin; hybrid; conjugates; antimalarial activity

\section{Introduction}

Despite worldwide efforts, malaria remains among the most dangerous infectious diseases. Malaria incidence has decreased significantly since 2010, but, unfortunately, after 2014, the number of malaria cases is increasing again, according to the World Health Organization [1]. The main reason is the elevated resistance to artemisinin combination therapy (ACT) [2]. In that respect, there is an urgent need for antimalarial agents with a novel mechanism of action (MOA).

During the last decade of the 20th century, the discovery of the non-mevalonate isoprenoid biosynthesis pathway as an essential target raised hope for potential therapeutic opportunities [3]. The pathway is proved to be essential for malaria parasites, while it is absent in mammalian hosts who generate isoprenoids exclusively via the mevalonate pathway $[4,5]$. The enzymes of the non-mevalonate pathway are located in the apicoplast organelle of malaria parasites, which only host small numbers of proteins, thus becoming attractive drug targets [6-8]. In this respect, the seminal work of Jomaa et al. [9] set the basis of an intense research work on compounds targeting the non-mevalonate pathway of the Plasmodium. These authors reported in 1999 that the antibiotic fosmidomycin (FSM, 1, Figure 1) inhibits the IspC (see Figure 1), which catalyzes the first committed step of the non-mevalonate pathway and is believed to be rate limiting. FSM, which was initially isolated from Streptomyces lavendulae [10,11], 
is a phosphonate structural analogue of the IspC substrate DOXP (4), which furthermore bears a hydroxamic acid moiety in replacement of the alpha hydroxy ketone of 4 and thus is not subject to hydrolysis by cellular phosphatases [12]. FSM may act as a transition state intermediate, with the hydroxamic acid group chelating the metal ion and the phosphono moiety resembling the phosphate group of 4 [13]. FSM was first developed as an antibacterial agent, but due to its less than ideal pharmacokinetics $[10,11,14]$, it was abandoned and later repositioned as a potential antimalarial, inhibiting a new different target compared to artemisinin (ART). The shortcomings of FSM have prompted attempts by several research groups to improve its activity by performing several chemical modifications, suitable for structure-activity relationship studies [15-22]. One of the most studied FSM's analogues is FR900098 (2), a phosphonic acid antibiotic, where the formyl group of FSM is replaced by an acetyl one. Although it is structurally very close to FSM, it is about twice as active as FSM in vitro and in a mouse model $[9,23,24]$.

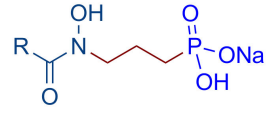

FSM , $1: R=H$ FR $900098,2: R=M e$<smiles>[R]OP([R])(=O)CCCNC=O</smiles>

$6: \mathrm{R}=$ Et or iPr or Pentyl or pivaloyl or benzoyl

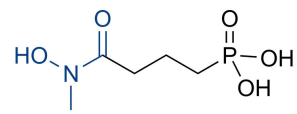

10<smiles>[R]C(=O)NCC(=O)N(O)CCCP(=O)(O)O</smiles>

13: $R=$ alkyl or aryl or allyl indol or catechol

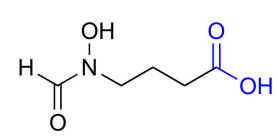

3

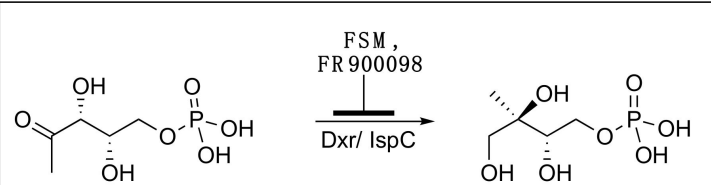

1-deoxy-D-xylulose 5-phosphate (DOXP/DXP), 4
2C-methyl-D-erythritol 4-phosphate (MEP), 5

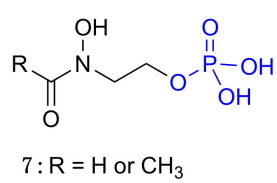<smiles>CN(O)C(=O)CCCc1nnn[nH]1</smiles>

11<smiles>NS(=O)(=O)OCCN(O)C=O</smiles>

8<smiles>[R]C(=O)Oc1ccc(COP(=O)(CCCC(=O)N(C)O)OCc2ccc(OC([R])=O)cc2)cc1</smiles><smiles>[R]C(=O)NCCCP(=O)(O)O</smiles>
12: $\mathrm{R}=$ alkyl or indol or aryl ester
or aryl alcohol or catechol or arylether

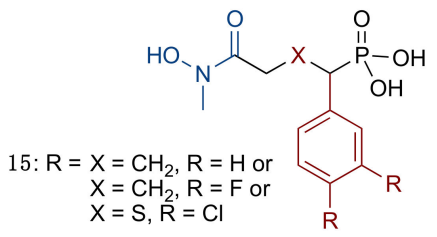

Figure 1. Structures of FSM, FR9000098, and various FSM derivatives.

In brief, structural modifications of FSM have focused on four main areas: (i) replacement of the phosphonate motif by (bio)isosteres $(\mathbf{3}, \mathbf{7}, \mathbf{8}, \mathbf{1 1})$, synthesis of phosphonate prodrugs $(\mathbf{6}, \mathbf{9})$ [25]; (ii) replacement or modification of the hydroxamate moiety that chelates the catalytically essential divalent cation, e.g., compounds 10-14 [26,27]; (iii) modulation of the aliphatic linker between the anionic anchor group and the chelating head group, e.g., compounds 14-15 [28]; and (iv) modification of the aliphatic chain by introduction of (typically aromatic) substituents, e.g., compounds 15 [22]. As an example, FR900098-prodrugs, where an acetyl group replaced the formyl one of the FSM, displayed improved in vitro and enhanced in vivo activity [9]. Furthermore, lipophilic phosphonate prodrug derivatives of FSM have previously been reported to display significantly enhanced antiplasmodial [29] and antimicrobial activities [30].

Recent studies have shown that the combination of two antimalarial drugs with different molecular targets in one single entity either as a hybrid or a conjugate proved to be more efficient against diseases, 
such as malaria and cancer [31]. Hybrid molecules are rather promising since they have less possibilities of developing drug resistance [32].

In this work, a synthesis and antiplasmodial evaluation along with the cytotoxicity of three focused families of compounds possessing the propyl phosphonate frame (ester or acid form) of FSM are reported. The first family contains five compounds: FSM, FR900098, and their phosphonate diesters $(\mathbf{1 6}, \mathbf{1 7})$, along with a dimeric form of FSM (18). The second family was constructed by attaching active antimalarial pharmacophores like ACQ (19-20) [33] or ART (21-23) [34,35] next to the carbonyl group of the hydroxamate thus preparing five new compounds (hybrids or conjugates). The third family (10 compounds, 26-33) possesses various amines connected to the hydroxamic function. For the last two compounds $(34,35)$, the hydroxamate moiety was replaced by o-phenylenediamine, thus changing the nature of the groups that might intervene in the chelation process (Figure 2).
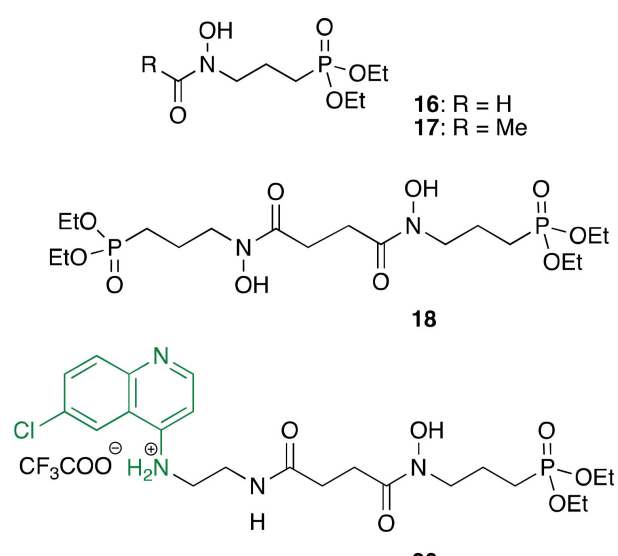

20<smiles>[R]NCCCN(CCCN[R])C(=O)CCC(=O)N(O)CCCP(=O)(OCC)OCC</smiles><smiles>[R]N1CCN(C(=O)CCC(=O)N(O)CCCP(=O)(OCC)OCC)CC1</smiles><smiles>Nc1ccccc1NCCCP([O])(=O)O</smiles>

34: $R^{1}=R^{2}=E t$ 35: $\mathrm{R}^{1}=\mathrm{Na}, \mathrm{R}^{2}=\mathrm{H}$<smiles>CCOP(=O)(CCCN(O)C(=O)CCC(=O)N1CCN(c2cccc3ncccc23)CC1)OCC</smiles>

$\mathrm{ACQ}$

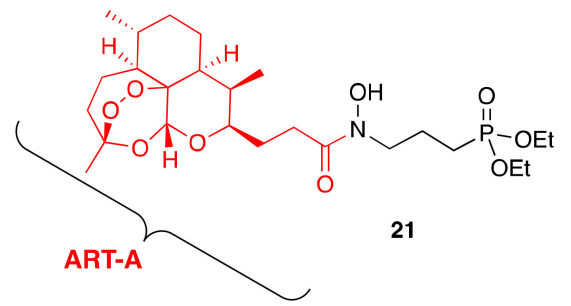<smiles>[R7]N([R7])C(=O)CCC(=O)N(O)CCCP(=O)(OCC)OCC</smiles>

26-31

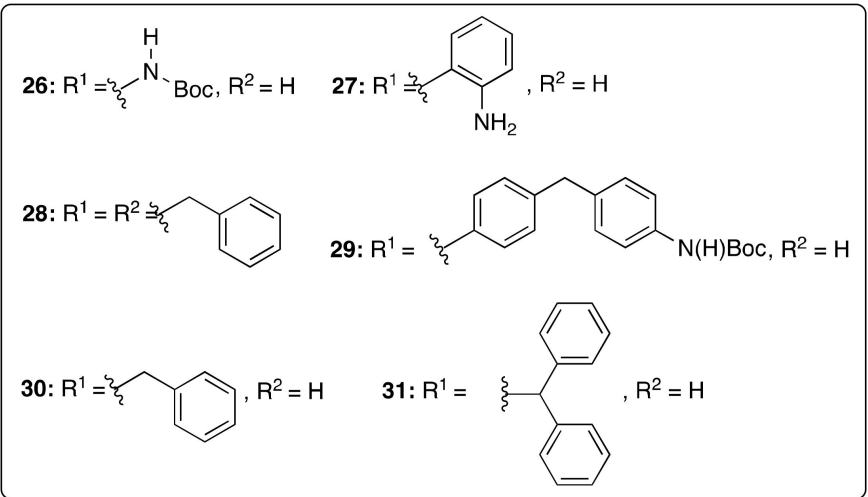

Figure 2. Structures of the FSM derivatives synthesized in this work (16-35).

\section{Results and Discussion}

\subsection{Synthesis of the Key Intermediate 39, FSM, FR9000098, and Dimer 18}

The first family includes the known compounds FSM and FR9000098 and their corresponding esters (compounds 16 and 17, Scheme 1), along with the tetraethylphosphonate dimer 18. Synthesis of FSM and FR900098 was conducted as reported in the literature by Suresh et al. [36] and Uh et al. [37]. tert-Butyl $N$-(benzyloxy)carbamate 36 and the bromophosphonic diester 37 were synthesized in an $89 \%$ 
and 50\% total yield, respectively, according to literature procedures [21,25]. Coupling of compounds 36 and 37 followed by TFA-mediated cleavage of the Boc protective group, yielded the key-intermediate synthon 39 in a $94 \%$ yield (two steps).<smiles>CCOP(=O)(CCCNOCc1ccccc1)OCC</smiles>

36 37

38

39

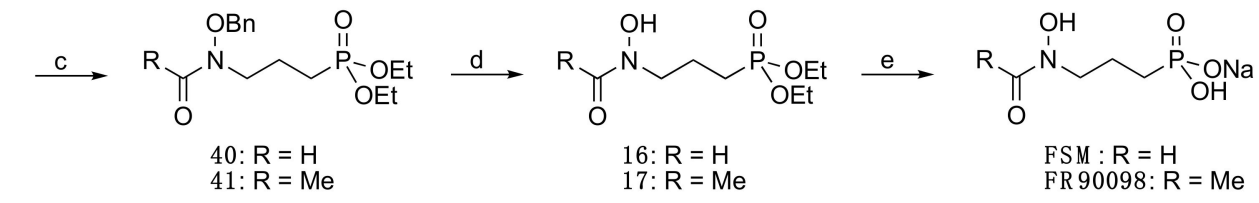<smiles>CCOP(=O)(CCCN(Cc1ccccc1)C(=O)CCC(=O)O)OCC1CCCC1</smiles>
42<smiles>[R]ON(CCCP(=O)(OCC)OCC)C(=O)CCC(=O)N([R])CCCP(=O)(OCC)OCC</smiles>

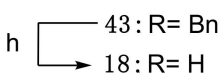

Scheme 1. Synthesis of key intermediate 39, FSM and FR9000098 monosodium salts, and FSM dimer 18; Reagents and conditions: (a) $\mathrm{NaH}, \mathrm{NaI}, \mathrm{DMF}$, $\mathrm{rt}$ to $60{ }^{\circ} \mathrm{C}, 17 \mathrm{~h}, 96 \%$; (b) TFA, $\mathrm{CH}_{2} \mathrm{Cl}_{2}, 0{ }^{\circ} \mathrm{C}$ to rt, $1.5 \mathrm{~h}, 98 \%$; (c) for 40: $\mathrm{HCOOH},\left(\mathrm{CH}_{3} \mathrm{CO}\right) \mathrm{O}_{2},-5{ }^{\circ} \mathrm{C}$ to rt, overnight, $91 \%$ and for $41: \mathrm{CH}_{3} \mathrm{COCl}_{2} \mathrm{Et}_{3} \mathrm{~N}$, DCM, $0{ }^{\circ} \mathrm{C}$ to rt, overnight, $98 \%$; (d) $\mathrm{H}_{2}, 10 \% \mathrm{Pd} / \mathrm{C}, \mathrm{MeOH}$, rt (3 h, 91\% for 16 and $4 \mathrm{~h}, 99 \%$ for 17); (e) (i) $\mathrm{TMSBr}, \mathrm{CH}_{2} \mathrm{Cl}_{2}, 0^{\circ} \mathrm{C}$ to rt, $8 \mathrm{~h}$ (ii) $6 \mathrm{~N}$ aq. $\mathrm{NaOH} / \mathrm{MeOH}$ ( $87 \%$ for $\mathrm{FSM}$ and $90 \%$ for FR900098 over 2 steps); (f) succinic anhydride, DIPEA, DMAP, THF, rt, $3 \mathrm{~h}, 88 \%$; (g) 39, $\mathrm{HBTU} \mathrm{Et}_{3} \mathrm{~N}, \mathrm{CHCl}_{3}, \mathrm{rt}, 3.5 \mathrm{~h}$, $61 \%$ (h) $\mathrm{H}_{2}, 10 \% \mathrm{Pd} / \mathrm{C}, \mathrm{MeOH}, \mathrm{rt}, 3 \mathrm{~h}, 50 \%$.

FSM was obtained in three steps and $72 \%$ total yield through formylation of the secondary amine of compound 39, hydrogenolysis of the benzyl protective group affording compound 16, and deprotection of the ethyl ester functions followed by a basic work-up.

Compounds 17 and FR900098 were obtained through a similar sequence of reactions involving acetylation of 39, hydrogenolysis, and ethyl ester groups' elimination. This sequence afforded better yields concerning acetylation and hydrogenolysis; thus compound $\mathbf{1 7}$ and FR900098 were obtained in a $68 \%$ and $83 \%$ yield, respectively. Based on this procedure, the FSM dimer 18 was synthesized (Scheme 1) by introducing a succinic acid spacer between the two fragments. Thus, compound 39 was allowed to react with succinic anhydride in the presence of a catalytic amount of 4-(dimethylamino)pyridine (DMAP), providing the acid 42 in an $88 \%$ yield. Then, coupling of 42 with the amine 39 was performed using the system $\mathrm{HBTU} / \mathrm{Et}_{3} \mathrm{~N}$ in chloroform to give the protected fosmidomycin dimer 43 in a 61\% yield. Cleavage of the benzyl groups by cat. hydrogenolysis led to the tetraethyl phosphonate 18 in moderate yield (50\%, Scheme 1).

\subsection{Synthesis of FSM-ACQ 19-20 and FSM-ART Conjugates 21-23}

Concerning the second family of compounds, namely the FSM conjugates, the FSM core is attached through a linker to either 4-amino-7chloro-quinoline (ACQ) or artemisinin frames. In this respect, five compounds were synthesized, two of them bearing the ACQ and three the ART moiety (compounds 19-20 (Scheme 2) and 21-23, respectively, Schemes 3 and 4). For the FSM-ACQ conjugates, two different ACQ amine derivatives (44 and 45), bearing a piperazine or an ethylenediamine linker attached in position 4 of the 4,7-dichloroquinoline [38], were prepared. While coupling of $O$-benzyl compound 42 with the piperazino chloroquinoline 44 worked well, the following cleavage of the benzyl group proved to be harsh, affording a mixture of compounds, where hydrogenolysis of the quinoline 
group was also observed. By reversing the sequence of reactions, thus first performing hydrogenolysis and then coupling of the hydroxamic acid 47 with piperazine 44 , the desired hybrid 19 was obtained in a $58 \%$ yield over two steps.<smiles>CCCCN(CCCP(=O)(OCC)OCC)C(=O)CCC(=O)O</smiles><smiles>CCOP(=O)(CCCN(O)C(=O)CCC(=O)O)OCC</smiles><smiles>CCOP(=O)(CCCN(O)C(=O)CCC(=O)N1CCN(c2ccnc3cc(Cl)ccc23)CC1)OCC</smiles><smiles>Pc1ccnc2cc(Cl)ccc12</smiles>

$44 \mathrm{R}=$ piperazine $45 \mathrm{R}=1,2$-diaminoethane<smiles>CCOP(=O)(CCCN(O)C(=O)CCC(=O)N1CCN(c2ccnc3cc(Cl)ccc23)CC1)OCC</smiles><smiles>CCOC(=O)OP(=O)(OCC)OCCCN(C(=O)CCC(=O)O)C(=O)OC</smiles>

48<smiles>[3H][V]</smiles><smiles>CCOC(=O)N(CCCP(=O)(OCC)OCC)C(=O)CCC(=O)NCCNc1ccnc2cc(Cl)ccc12</smiles><smiles>CCOP(=O)(CCCN(O)C(=O)CCC(=O)NCCNc1ccnc2cc(Cl)ccc12)OCC(F)(F)F</smiles>

Scheme 2. Synthesis FSM-ACQ conjugates 19 and 20; Reagents and conditions: (a) 44, HBTU, Et ${ }_{3} \mathrm{~N}$, $\mathrm{CHCl}_{3}, \mathrm{rt}, 3.5 \mathrm{~h}, 61 \%$ (b) $\mathrm{H}_{2}, 10 \% \mathrm{Pd} / \mathrm{C}, \mathrm{MeOH}, \mathrm{rt}, 3$ h; (c) $\mathrm{H}_{2}, 10 \% \mathrm{Pd} / \mathrm{C}, \mathrm{MeOH}, \mathrm{rt}, 5$ h, 97\%; (d) 44, HBTU, DIPEA, $\mathrm{CHCl}_{3}$, rt, 2 h, 60\%; (e) $\mathrm{Boc}_{2} \mathrm{O}, \mathrm{Et}_{3} \mathrm{~N}$, DMAP, $\mathrm{CH}_{2} \mathrm{Cl}_{2}$, rt, overnight, 30\%; (f) 45, HBTU, $\mathrm{Et}_{3} \mathrm{~N}, \mathrm{CHCl}_{3}, \mathrm{DMF}, 4 \mathrm{~h}, 50 \%$; (g) TFA, $\mathrm{CH}_{2} \mathrm{Cl}_{2}$, overnight, $60 \%$.

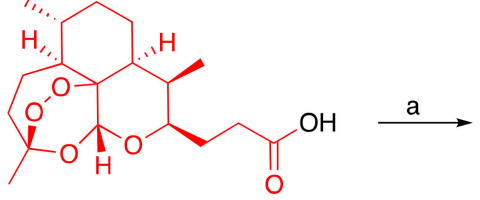

50<smiles></smiles>

$\mathrm{b} \longrightarrow \mathrm{51:} \mathrm{R}=\mathrm{Bn}$
21: $\mathrm{R}=\mathrm{H}$

Scheme 3. Synthesis of FSM-ART conjugate 21; Reagents and conditions: (a) 39, $\mathrm{HBTU}, \mathrm{Et}_{3} \mathrm{~N}, \mathrm{CH}_{2} \mathrm{Cl}_{2}$, overnight, $50 \%$; (b) $\mathrm{H}_{2}, 10 \% \mathrm{Pd} / \mathrm{C}, \mathrm{MeOH}, \mathrm{rt}, 4 \mathrm{~h}, 90 \%$.

For the second hybrid, possessing an ethylene diamine linker, this sequence of reactions could not be applied. A complex mixture of compounds was obtained that was difficult to purify. In this respect, the Boc group was used as alternative protection for the hydroxamic function; treatment of 47 with the system $\mathrm{Boc}_{2} \mathrm{O} / \mathrm{Et}_{3} \mathrm{~N} / \mathrm{DMAP}$ afforded acid 48 and then followed a coupling reaction with the primary amino group of compound 45 to give the desired compound 49 in a 50\% yield, after FCC purification. Boc-deprotection, by TFA-mediated acidolysis, yielded the FSM-ACQ hybrid 20 in a $60 \%$ yield. 


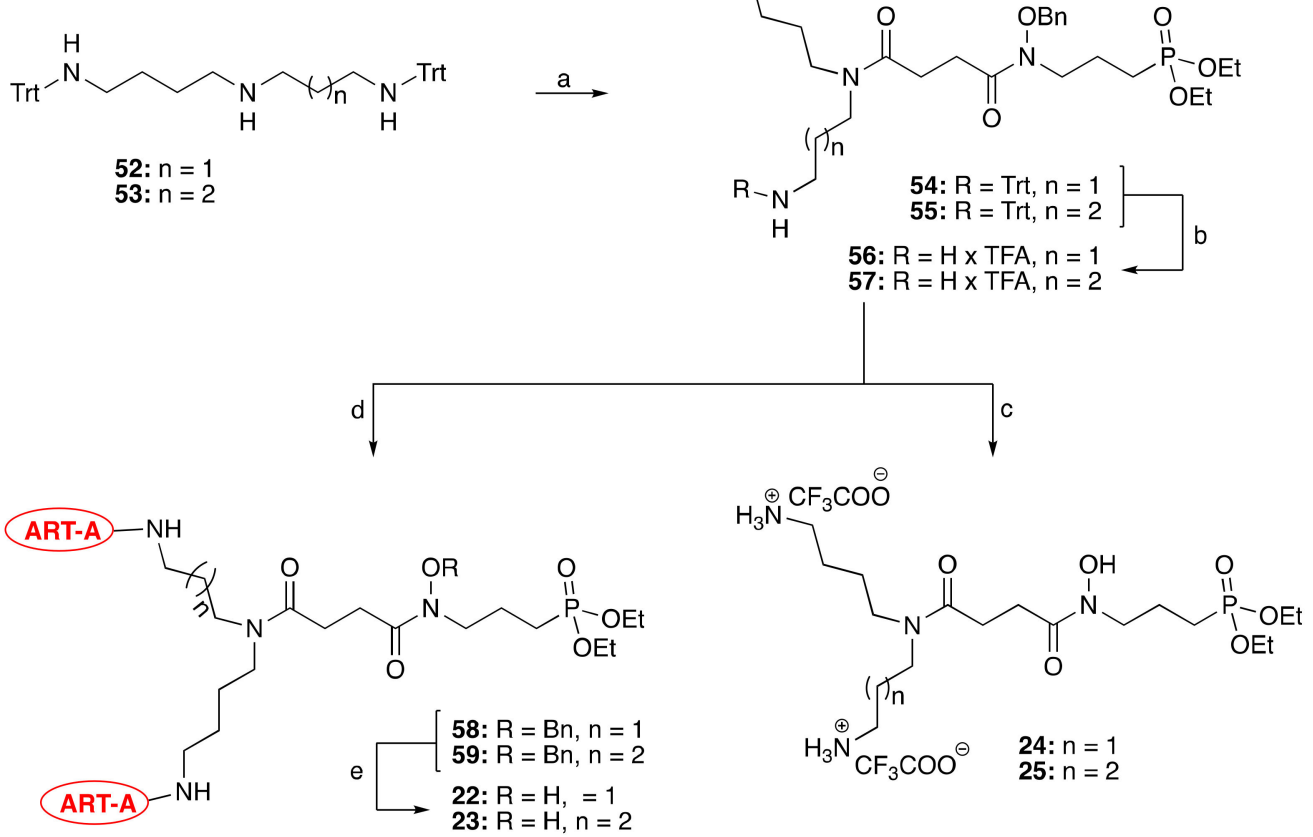

Scheme 4. Synthesis of the FSM-ART conjugates 22-23 and FSM derivatives 24-25; Reagents and conditions: (a) 42, HBTU, DIPEA, $\mathrm{CHCl}_{3}, \mathrm{rt}, 7 \mathrm{~h}$ (72\% for 54 and $96 \%$ for 55) (b) TFA, TFE, $\mathrm{CH}_{2} \mathrm{Cl}_{2}, 5 \mathrm{~h}$ (90\% for 56 and $98 \%$ for 57); (c) $\mathrm{H}_{2}, 10 \% \mathrm{Pd} / \mathrm{C}, \mathrm{MeOH}, \mathrm{rt}, 6.5 \mathrm{~h}$ (91\% for 24 and 95\% for 25); (d) $2 \times 50$, HBTU, DIPEA, $\mathrm{CH}_{2} \mathrm{Cl}_{2}$, overnight, 50\%; (e) $\mathrm{H}_{2}, 10 \% \mathrm{Pd} / \mathrm{C}, \mathrm{MeOH}, \mathrm{rt}, 4 \mathrm{~h}$ (60\% for 22 and $80 \%$ for 23).

For FSM-ART conjugates, one artemisinin fragment was first introduced through the acid derivative 50 (Scheme 3), which was prepared as previously described [35]. Reaction of compound 50 with benzyloxyamine 39 under peptide coupling conditions afforded derivative 51, which upon hydrogenolysis reaction led to FSM-ART hybrid 21 in a $45 \%$ yield over 2 steps, after FCC purification.

Moreover, based on our recent work, where hybrids possessing two artemisinin moieties linked with polyamine spacers, such as spermidine or homospermidine, present very good activities against Plasmodium falciparum [28], compounds 22 and 2, possessing a FSM moiety attached through a spermidine or homospermidine linkers to two artemisinin moieties, were synthesized. Protected spermidine and homospermidine derivatives 52 and 53 , respectively, were prepared according to the procedure described in our previous work [35]. Reaction of $\mathbf{5 2}$ and $\mathbf{5 3}$ with the acid $\mathbf{4 2}$ under different and optimal coupling conditions afforded compounds 54 and 55 in $72 \%$ and $96 \%$ yields, respectively. One-pot deprotection of both benzyl and trityl groups under catalytic hydrogenation conditions unfortunately afforded a mixture of compounds. We thus proceeded in two steps: first with TFA-mediated acidolysis of the trityl groups, followed by hydrogenation for the benzyl group cleavage. The two-step procedure afforded the valuable intermediates 24 and 25 in $91 \%$ and $95 \%$ yields, respectively (Scheme 4).

Attempts to couple compounds $\mathbf{2 4}$ or $\mathbf{2 5}$ with the artemisinin acid derivative $\mathbf{5 0}$ as for the ACQ derivatives failed to proceed in a clean manner; a mixture of derivatives bearing two and three artemisinin moieties appeared in the mass spectrum, also indicating coupling on the $\mathrm{N}-\mathrm{OH}$ function. So, precursors $\mathbf{5 6}$ and $\mathbf{5 7}$ were allowed to react with artemisinin acid $\mathbf{5 0}$ (Scheme 4) using HBTU as the coupling agent, in order to afford the benzylated derivatives 58 and 59 in a 50\% yield. The latter were then hydrogenated, leading to the final FSM-ART hybrids 22 and 23 in $60 \%$ and $80 \%$ yields, respectively, after flash column chromatography (FCC) purification. 


\subsection{Synthesis of FSM Derivatives $\mathbf{2 6 - 3 5}$}

The third family of FSM derivatives synthesized is based on the functionalization of the acid 42. This compound can be an interesting platform, where the main functions of FSM are present, and a propyl carboxylic acid is attached as a linker. In this respect, the two first compounds of this family ( 56 and $\mathbf{5 7}$, Scheme 4 ) have already been synthesized as valuable intermediates in the synthesis of FSM-ART conjugates with spermidine and homospermidine linkages. By using analogous peptide coupling conditions, eight new compounds were synthesized possessing various amino and/or amido frameworks connected to the hydroxamic function (Scheme 5).<smiles>CCOP(=O)(CCCN(OCc1ccccc1)C(=O)CCC(=O)O)OCC</smiles>

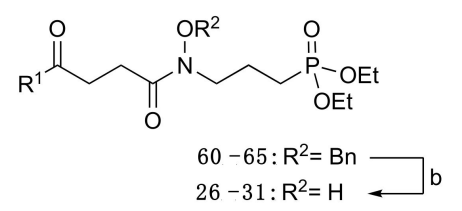

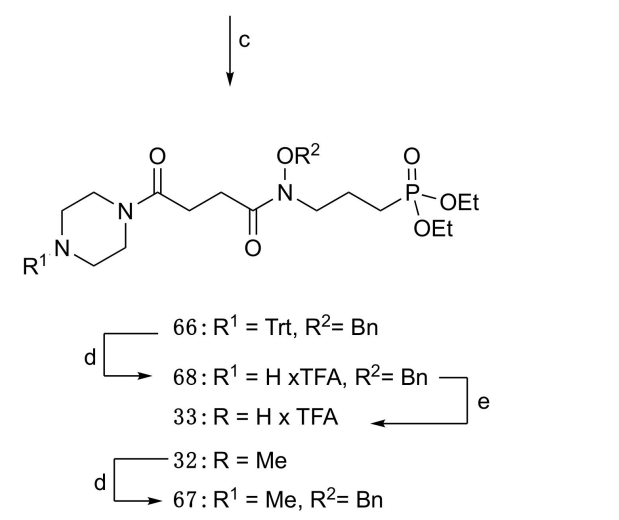

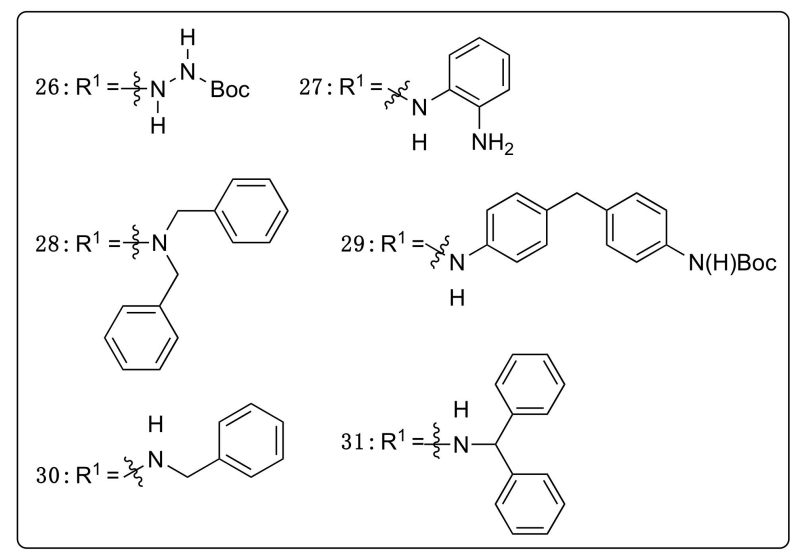

Scheme 5. Synthesis of FSM-amido derivatives 26-33; Reagents and conditions: (a) $\mathbf{R}^{\mathbf{1}} \mathbf{H}, \mathrm{HBTU}$, DIPEA, $\mathrm{CH}_{2} \mathrm{Cl}_{2}$, rt, 3-6 h, 62\%-84\%; (b) $\mathrm{H}_{2}, 10 \% \mathrm{Pd} / \mathrm{C}$, MeOH, rt, 3-5 h, 80\%-90\%; (c) $\mathbf{R}^{1} \mathbf{H}, \mathrm{HBTU}$, DIPEA, $\mathrm{CH}_{2} \mathrm{Cl}_{2}, \mathrm{rt}, 2 \mathrm{~h}, 70 \%$ for 66 and $6 \mathrm{~h}, 84 \%$ for 68 ; (d) TFA, TFE, $\mathrm{CH}_{2} \mathrm{Cl}_{2}, 0{ }^{\circ} \mathrm{C}$ to $\mathrm{rt}, 1 \mathrm{~h}, 70 \%$; (e) $\mathrm{H}_{2}, 10 \% \mathrm{Pd} / \mathrm{C}, \mathrm{MeOH}, \mathrm{rt}, 2 \mathrm{~h}, 90 \%$ for 32 and $4 \mathrm{~h}, 60 \%$ for 33 .

Among the different amine reagents, Boc-monoprotected dianiline (used for derivative 29) and Trt-piperazine (used for derivative 66) were synthesized according to known procedures [39,40], while all other amines were commercially available.

Finally, two more compounds were synthesized, where the hydroxamic part was replaced by a fragment that potentially can interact with metal ions as is the case and the role of the hydroxamic function of FSM. In this respect, o-phenylenediamine (a known pharmacophore) was chosen due to its chelating capacity [41]. Synthesis of the two final compounds $\mathbf{3 4}$ and $\mathbf{3 5}$ was straightforward. Alkylation of $o$-phenylenediamine under sonicating conditions using the already available bromophosphonate 37 afforded in fair yield compound 34, which upon ethyl ester deprotection, followed by basic work-up, led to compound 35 (Scheme 6).

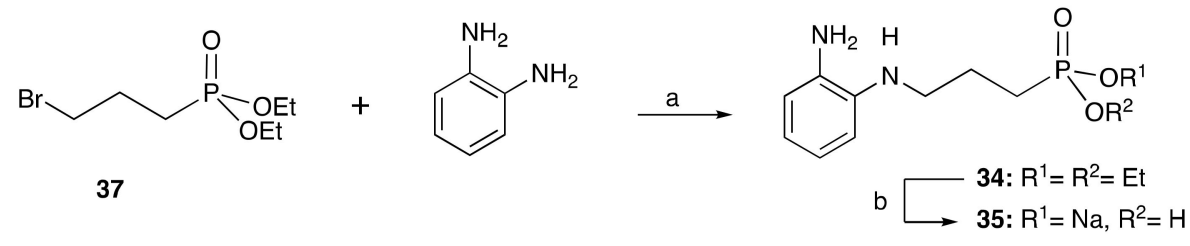

Scheme 6. Synthesis of phosphonate derivatives 34 and 35; Reagents and conditions: (a) DBU, DMF, $1 \mathrm{~h}$, ultrasound, rt, 33\%; (b) (i) TMSBr, DCM, $0{ }^{\circ} \mathrm{C}$ to rt, $8 \mathrm{~h}$ (ii) $6 \mathrm{~N}$ aq. $\mathrm{NaOH} / \mathrm{MeOH} 75 \%$ over 2 steps. 
The synthesized compounds were evaluated for their antiplasmodial activity against the CQ-resistant P. falciparum FcB1/Colombia strain [42,43], using as control drugs FSM, FR900098, ART, and CQ (see Figure 3). Moreover, their cytotoxicity was measured, as previously reported, upon the primary human fibroblast cell line AB943, which allowed the calculation of their selectivity index (SI) [35].<smiles>O=CN(O)CCCP(=O)(O)O</smiles>

FSM, 1<smiles>CC(=O)N(O)CCCP(=O)(O)O</smiles>

FR900098, 2

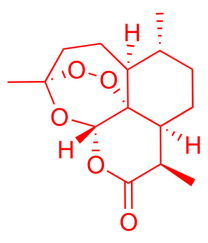

ART

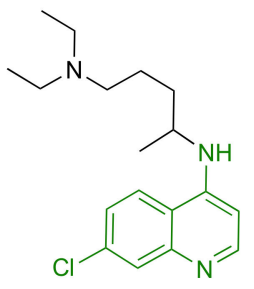

CQ

Figure 3. Structures of the control drugs (FSM, FR900098, ART, CQ).

Specifically, $\mathrm{IC}_{50}(\mu \mathrm{M})$ values for the antiplasmodial activities were determined from four independent experiments as the mean values \pm standard deviations. $\mathrm{IC}_{50}(\mu \mathrm{M})$ values for the cytotoxicity activities were determined from two independent experiments as the mean values \pm standard deviations. $\mathrm{IC}_{50}$, SIs (ratio between $\mathrm{IC}_{50}(\mu \mathrm{M})$ of cytotoxicity/ $/ \mathrm{IC}_{50}(\mu \mathrm{M})$ of the antiplasmodial activity), and XLogGP3 values for the FSM derivatives, hybrid, and conjugates are reported in Table 1 . The $\mathrm{IC}_{50}$ values of ART, FSM, FR900098, and CQ were also measured and are provided as controls.

Table 1. Evaluation of antiplasmodial activities of synthesized compounds with CQ-resistant P. falciparum FcB1/Colombia strain and selectivity indexes (SI).

\begin{tabular}{|c|c|c|c|c|}
\hline Compound & MW & $C \log P^{1}$ & $\mathrm{IC}_{50}(\mu \mathrm{M})$ & $\mathrm{SI}^{2}$ \\
\hline FSM & 205.08 & -2.22 & $15.0 \pm 1.7$ & $>6.6$ \\
\hline 17 & 253.23 & -0.43 & $>100$ & - \\
\hline FR900098 & 219.11 & -2.24 & $7.0 \pm 0.0$ & $>14.2$ \\
\hline 18 & 504.45 & -1.22 & $>100$ & - \\
\hline 19 & 540.98 & 1.42 & $2.7 \pm 0.5$ & 23.9 \\
\hline 20 & 628.97 & 2.24 & $4.2 \pm 0.9$ & 23.7 \\
\hline 21 & 533.60 & 3.22 & $28.0 \pm 11.6$ & - \\
\hline 22 & 1083.31 & 4.97 & $0.36 \pm 0.09$ & 94.1 \\
\hline 23 & 1097.33 & 5.33 & $0.65 \pm 0.26$ & 34.0 \\
\hline 24 & 667.56 & -4.62 & $>100$ & - \\
\hline 25 & 680.58 & -4.26 & $46.2 \pm 8.0$ & - \\
\hline 26 & 425.42 & -0.35 & $86.0 \pm 1.4$ & - \\
\hline 27 & 401.40 & -0.37 & $81.0 \pm 2.8$ & - \\
\hline 28 & 490.54 & 1.92 & $38.7 \pm 10.0$ & - \\
\hline 29 & 591.64 & 2.80 & $22.7 \pm 1.9$ & 1.7 \\
\hline 30 & 400.41 & 0.25 & $>100$ & - \\
\hline 31 & 476.51 & 1.94 & $44.2 \pm 9.5$ & - \\
\hline 32 & 393.42 & -1.25 & $>100$ & - \\
\hline 33 & 493.42 & -3.09 & $>100$ & - \\
\hline 34 & 286.31 & 1.56 & $8.2 \pm 2.7$ & 3.7 \\
\hline 35 & 230.20 & -0.24 & $>100$ & - \\
\hline ART & 282.34 & 2.90 & $55.0 \pm 13.6(\mathrm{nM})$ & $>4545$ \\
\hline CQ & 318.89 & 5.70 & $72.0 \pm 7.4(\mathrm{nM})$ & 347 \\
\hline
\end{tabular}

Concerning the first family of compounds (FSM, 17, FR900098, 18), it was noticed that phosphonate esters are inactive. For example, FR900098's diethyl phosphonate analogue $\mathbf{1 7}$ and the dimer 18, which possesses two diethylphosphonate ester FSM frames linked together with a succinic acid spacer, have $\mathrm{IC}_{50}$ values $>100 \mu \mathrm{M}$. FSM appears 2-fold less active than FR900098, with $\mathrm{IC}_{50}$ values 
of 15.0 and $7.0 \mu \mathrm{M}$ respectively, while their selectivity indexes also follow the same trends ( $>6.6 \mathrm{vs}$. $>14.2 \mu \mathrm{M}$ respectively).

The second family, constructed by introducing next to the carbonyl group of the FSM hydroxamate group active antimalarial pharmacophores like aminochloroquinoline or artemisinin, presents very interesting results. The hybrid compounds with aminochloroquinoline 19 and 20 showed strong and comparable activities of 2.7 and $4.2 \mu \mathrm{M}$, respectively. Compound 19 possesses the structure of piperazine linked through an amide chain to the FSM diester fragment. The $\mathbf{1 9}$ and $\mathbf{2 0}$ compounds are 3.5-5.5 times more active than FSM itself and more than 25-40-fold more active in comparison to the diester compound 17. Their activities are lower but closer to the $C Q$, indicating a major influence of the ACQ fragment, largely compensating the absence of acid functionality on the FSM. In addition, they showed higher selectivity indexes in comparison to FSM but much lower in comparison to CQ.

Concerning the hybrid compounds containing artemisinin, we observed a weaker activity for compound 21, where one artemisinin moiety is linked directly to the FSM diester fragment $\left(\mathrm{IC}_{50}=28.0 \mu \mathrm{M}\right)$. On the contrary, the conjugation of the two ART frames with one FSM diester fragment through a spermidine and to a lesser extent to an homospermidine linker $(\mathbf{2 2}, \mathbf{2 3})$ afforded the most active molecules of our series with $\mathrm{IC}_{50}$ values of 0.36 and $0.65 \mu \mathrm{M}$; and the best selectivity among all new compounds, with SI values of 94 and 34, respectively. Here, again, it is observed that the $\mathrm{IC}_{50}$ values are 6.5-12 times higher than ART itself but much lower than FSM's (23-41 fold). These values indicate a stronger influence of the ART fragment to the conjugates. It is noteworthy that all molecules of this family, which exhibit strong antimalarial activities, possess the diethyl phosphonate group.

According to our recently reported work on other antimalarial hybrid compounds [35], the presence of two artemisinin moieties linked through spermidine or homospermidine to an amide chain bearing a third endoperoxide $(\mathrm{GMeP})$ gave $\mathrm{IC}_{50}$ values of the order of $10 \mathrm{nM}$. In the case of compounds 22 and 23, the presence of FSM diester (in the place of GMeP) was observed again, even if the activities were lower in this case, probably confirming that hybrid compounds with two different potential targets of Plasmodium can be an interesting option in the search for new antimalarial compounds.

Compounds possessing only the spermidine or homospermidine fragments attached through an amido linker to FSM diester $(\mathbf{2 4}, \mathbf{2 5})$ are much less active; however, a better $\mathrm{IC}_{50}$ value was observed for compound 25 bearing the homospermidine frame. Among the other compounds of this third family, those bearing two aromatic rings attached to the amido function $(28,29,31)$ present activities in the range between 22 and $44 \mu \mathrm{M}$, while compounds 26, 27, and 30 are inactive. Nevertheless, the second-best compound of this family series (29) is cytotoxic since it has an SI value of only 1.7. Finally, the two compounds possessing a piperazine or $N$-methyl piperazine fragment $(32,33)$ are inactive, indicating that piperazine alone (as spermidine and homospermidine alone) lacks activity like the diester 17 . For the last two compounds of the third family $(34,35)$, where the hydroxamic fragment was replaced by an ortho-benzenediamine fragment, we observed good activity for the diester $34\left(\mathrm{IC}_{50}=8.2 \mu \mathrm{M}\right)$, while the mono sodium salt of the corresponding diacid (35) is inactive. However, despite the good antimalarial activity of 34 , it seems to be cytotoxic, with an SI value of only 3.7.

In Table 1, the MWs, $\mathrm{IC}_{50}$ values, and the evaluation of the XLogGP3 SwissADME values according to the online calculation [44] are also reported. The software can combine physicochemical properties along with pharmacokinetics predictions for the drug likeness of the examined compounds. Since the families of the synthesized and tested compounds are quite different, we first examined and compared the values for each family. The active and known compounds FSM and FR900098 show the most negative values ( -2.22 and -2.24 , respectively) in comparison to values of -0.43 and -1.22 for diester 17 and the dimer 18. For the second and most promising family of compounds, values vary between +1.42 and +5.33 , with the two most active compounds having the highest ones. Concerning the third family of compounds, the most active show values between +1.92 and +2.80 , while the inactive ones have negative values. In summary, apart from the first family, where all compounds possess negative XLOGP3 ADME values, the others show positive values for the active ones, the highest being for the most actives. Even if the calculation of the XLOGP3 values takes into consideration a number of 
different parameters, including the molecular weight, we feel that XLOGP3 could be one of many valuable tools to include when searching to optimize structures of the same family.

Results concerning comparative activities and the XLogGP3 SwissADME for all compounds tested indicated that different factors intervene for the activities of the compounds. Most important of them are related to the fragment-attached FSM derivative and to the linker next to that. The influence of the acid group of the FSM has to be more extensively studied, as its rol is not apparent in regard to some of the results obtained. Moreover, it is noteworthy to observe that compounds with a potential protonation site on the fragment adjacent to the FSM core (compounds 19, 20,34) can be very active, along with those possessing two highly active pharmacophores (compounds 22, 23) connected through a polyamino linker to the FSM core.

In conclusion, a series of FSM analogs, derivatives, and conjugates with ART and ACQ were synthesized and evaluated against P. falciparum. The most active compounds, which in addition to possessing a good SI, are those that combine two ART frames with the one of FSM diester, through a spermidine or homospermidine linker and exhibit $\mathrm{IC}_{50}$ values of 0.36 and $0.65 \mu \mathrm{M}$, respectively (compounds 22 and 23). Interestingly, the hybrid compounds with one ACQ frame (compounds 19 and 20) are 3.5-5.5 times more active than FSM itself with fairly good SIs. While for FSM and FR900098 the monosodium salt $\mathbf{1 7}$ is the most active form, for the hybrid compounds mentioned above, the diethyl phosphonates 19 and 20 show the best activity.

Further work is in progress to examine whether for the most active compounds, (i) the diester forms are better than the acidic ones and (ii) if they are active against strains of $P$. falciparum showing a different resistance status. Finally, according to our recent findings on hybrid compounds possessing the endoperoxide GMeP [35], we are now engaged in incorporating this frame in a series of FSM analogues and evaluating them.

\section{Materials and Methods}

\subsection{General Methods}

Melting points were determined with a Buchi SMP-20 apparatus and are uncorrected. ${ }^{1} \mathrm{H}$ NMR spectra were obtained at $600.13 \mathrm{MHz}$ and ${ }^{13} \mathrm{C}$ NMR spectra at $150.90 \mathrm{MHz}$ on a Bruker AVANCEIII HD spectrometer. Chemical shifts $(\delta)$ are indicated in parts per million (ppm) downfield from TMS and coupling constants $(J)$ are reported in hertz (Copies of NMR spectra are available in the Supplementary Materials. ESI-HRMS spectra were recorded on a Waters Q-TOF UPLC Xevo G2 and ESI mass spectra were recorded at $30 \mathrm{~V}$, on a Micromass-Platform LC spectrometer using $\mathrm{MeOH}$ as solvent. All solvents were dried and/or purified according to standard procedures prior to use. Anhydrous $\mathrm{Na}_{2} \mathrm{SO}_{4}$ was used for drying solutions, and the solvents were then routinely removed at ca. $40^{\circ} \mathrm{C}$ under reduced pressure using a rotary vacuum evaporator. All reagents employed in the present work were commercially available and used without further purification. When required, reactions were carried out under dry argon atmosphere in preflamed glassware. Flash column chromatography (FCC) was performed on Merck silica gel 60 (230-400 mesh) and analytical thin layer chromatography (TLC) was performed on Merck silica gel $60 \mathrm{~F}_{254}(0.2 \mathrm{~mm})$ precoated on aluminum foil. Spots on the TLC plates were visualized with UV light at $254 \mathrm{~nm}$ and ninhydrine solution or charring agents.

\subsection{Experimental Procedures}

\subsubsection{Synthesis of FSM Dimer 18}

4-((Benzyloxy)(3-(diethoxyphosphoryl)propyl)amino)-4-oxobutanoic acid (42): To an ice-cold solution of protected amine 39 ( $1 \mathrm{mmol})$ and 4-dimethylaminopyridine (DMAP) (0.1 mmol) in freshly distilled tetrahydrofuran (THF) (2 mL), N,N-diisopropylethylamine (DIPEA) $(1.5 \mathrm{mmol})$ was added. Then, the addition of succinic anhydride $(1.1 \mathrm{mmol})$ was followed in small portions over $30 \mathrm{~min}$ and the reaction mixture was stirred at ambient temperature for $3 \mathrm{~h}$. Upon completion of the reaction, 
THF was removed under reduced pressure and the residue thus obtained was diluted with $\mathrm{CH}_{2} \mathrm{Cl}_{2}$ and washed with $5 \%$ aqueous citric acid, water, and brine. The organic layer was dried over $\mathrm{Na}_{2} \mathrm{SO}_{4}$ and evaporated to dryness under vacuum. The residue was subjected to FCC to give acid 42 as yellow oil (283 mg, 88\%); $\mathrm{R}_{\mathrm{f}}\left(\mathrm{CHCl}_{3} / \mathrm{MeOH}\right.$ 95:5): 0.15; ${ }^{1} \mathrm{H}$ NMR $\left(\mathrm{CDCl}_{3}\right): \delta 7.37(5 \mathrm{H}, \mathrm{s}), 4.84(2 \mathrm{H}, \mathrm{s}), 4.16-3.98$ $(4 \mathrm{H}, \mathrm{m}), 3.71(2 \mathrm{H}, \mathrm{t}, J=6.2 \mathrm{~Hz}), 2.71(2 \mathrm{H}, \mathrm{t}, J=6.4 \mathrm{~Hz}), 2.62(2 \mathrm{H}, \mathrm{t}, J=6.4 \mathrm{~Hz}), 1.98-1.86(2 \mathrm{H}, \mathrm{m})$, $1.79-1.68(2 \mathrm{H}, \mathrm{m}), 1.29(6 \mathrm{H}, \mathrm{t}, J=7.1 \mathrm{~Hz}) ;{ }^{13} \mathrm{C} \mathrm{NMR}\left(\mathrm{CDCl}_{3}\right): \delta 175.9,134.3,129.3,129.1,128.8,76.5,61.9$, 29.0, 28.7, 27.3, 23.2, 22.3, 20.2, 16.4; ${ }^{31} \mathrm{P} \mathrm{NMR}\left(\mathrm{CDCl}_{3}\right): \delta 34.18$; ESI-MS (30eV): $\mathrm{m} / z$ 825.04 [2M + Na] $]^{+}$, $440.16[\mathrm{M}+\mathrm{K}]^{+}, 424.16[\mathrm{M}+\mathrm{Na}]^{+}, 402.12[\mathrm{M}+\mathrm{H}]^{+}$.

Tetraethyl ((4,7-dioxo-1,10-diphenyl-2,9-dioxa-3,8-diazadecane-3,8-diyl) bis(propane-3,1-diyl)) bis(phosphonate) (43): To a solution of acid $42(60 \mathrm{mg}, 0.15 \mathrm{mmol})$ and HBTU $(63 \mathrm{mg}, 0.165 \mathrm{mmol})$ in $\mathrm{CHCl}_{3}(1.4 \mathrm{~mL})$, amine $39(45 \mathrm{mg}, 0.15 \mathrm{mmol})$, and $\mathrm{Et}_{3} \mathrm{~N}(32 \mu \mathrm{L}, 0.225 \mathrm{mmol})$ were added. After $3.5 \mathrm{~h}$, the reaction mixture was diluted with $\mathrm{CHCl}_{3}$, washed with $5 \%$ aqueous citric acid, water, $5 \%$ aqueous $\mathrm{NaHCO}_{3}$, water, and brine. The organic layer was dried over $\mathrm{Na}_{2} \mathrm{SO}_{4}$, filtered, and evaporated to dryness under reduced pressure. The residue thus obtained was subjected to FCC, affording the corresponding pure conjugate; Yellow oil $(72 \mathrm{mg}, 70 \%) ; \mathrm{R}_{\mathrm{f}}\left(\mathrm{CHCl}_{3} / \mathrm{MeOH} 95: 5\right): 0.37 ;{ }^{1} \mathrm{H} \mathrm{NMR}\left(\mathrm{CDCl}_{3}\right)$ $\delta$ 7.41-7.34 (m, 10H), $4.90(\mathrm{~s}, 4 \mathrm{H}), 4.12-4.02(\mathrm{~m}, 8 \mathrm{H}), 3.71(\mathrm{t}, J=6.4 \mathrm{~Hz}, 4 \mathrm{H}), 2.77(\mathrm{~s}, 4 \mathrm{H}), 1.99-1.89(\mathrm{~m}$, $4 \mathrm{H}), 1.75-1.69(\mathrm{~m}, 4 \mathrm{H}), 1.29(\mathrm{t}, J=7.1 \mathrm{~Hz}, 12 \mathrm{H}) ;{ }^{13} \mathrm{C} \mathrm{NMR}\left(\mathrm{CDCl}_{3}\right) \delta 175.5,134.5,129.2,128.9,128.7$, 76.5, 61.6, 26.9, 23.5, 22.5, 20.3, 16.5; ESI-MS (30eV): $m / z 723.42\left[\mathrm{M}+\mathrm{K}^{+}, 707.54[\mathrm{M}+\mathrm{Na}]^{+}, 685.54\right.$ $[\mathrm{M}+\mathrm{H}]^{+}, 384.64\left[\mathrm{M}-\mathrm{C}_{14} \mathrm{H}_{23} \mathrm{NO}_{4} \mathrm{P}\right]^{+}$.

Tetraethyl-((succinylbis(hydroxyazanediyl))bis (propane-3,1-diyl))bis(phosphonate) (18): A solution of $43(50 \mathrm{mg}, 0.073 \mathrm{mmol})$ in methanol $(3 \mathrm{~mL})$ was subjected to hydrogenolysis over $10 \% \mathrm{Pd} / \mathrm{C}$ $(15 \mathrm{mg})$ at ambient temperature for $3 \mathrm{~h}$. Thus, the reaction mixture was filtered through Celite and the filter cake was washed several times with methanol. After evaporation of the solvent to dryness under reduced pressure, the residue was subjected to FCC, affording the corresponding the dimer 18; Yellow oil (18 mg, 50\%); $\mathrm{R}_{\mathrm{f}}\left(\mathrm{CHCl}_{3} / \mathrm{MeOH} 95: 5\right): 0.12 ;{ }^{1} \mathrm{H} \mathrm{NMR}\left(\mathrm{CDCl}_{3}\right) \delta 9.92(\mathrm{~s}, 1 \mathrm{H}), 4.11-4.01$ $(\mathrm{m}, 8 \mathrm{H}), 3.75-3.59(\mathrm{~m}, 4 \mathrm{H}), 2.82(\mathrm{~s}, 4 \mathrm{H}), 1.97-1.85(\mathrm{~m}, 4 \mathrm{H}), 1.82-1.71(\mathrm{~m}, 4 \mathrm{H}), 1.30(\mathrm{t}, J=7.0 \mathrm{~Hz}, 12 \mathrm{H})$; ${ }^{13} \mathrm{C} \mathrm{NMR}\left(\mathrm{CDCl}_{3}\right) \delta 170.7,62.0,49.0$ 27.8, 22.9, 21.9, 19.5, 16.4; HRMS (ESI/Q-TOF): $\mathrm{m} / \mathrm{z} 527.1907$ $[\mathrm{M}+\mathrm{Na}]^{+}$for the compound $\mathrm{C}_{18} \mathrm{H}_{38} \mathrm{~N}_{2} \mathrm{O}_{10} \mathrm{P}_{2}$ requires 527.1894.

\subsubsection{Synthesis of FSM-ACQ Derivatives 19 and 20}

4-((3-(Diethoxyphosphoryl)propyl)(hydroxy)amino)-4-oxobutanoic acid (47): A solution of $\mathbf{4 2}$ $(80 \mathrm{mg}, 0.2 \mathrm{mmol})$ in methanol $(3 \mathrm{~mL})$ was subjected to hydrogenolysis over $10 \% \mathrm{Pd} / \mathrm{C}(12 \mathrm{mg})$ at ambient temperature for $5 \mathrm{~h}$. Thus, the reaction mixture was filtered through Celite and the filter cake was washed several times with methanol. After evaporation of the solvent to dryness under reduced pressure, the residue was subjected to FCC, affording pure 47; Orange oil (60.4 mg, 97\%); $\mathrm{R}_{\mathrm{f}}\left(\mathrm{CHCl}_{3} / \mathrm{MeOH}\right.$ 9:1): 0.23; ${ }^{1} \mathrm{H}$ NMR $\left(\mathrm{CDCl}_{3}\right) \delta 4.14-4.02(\mathrm{~m}, 4 \mathrm{H}), 3.73(\mathrm{t}, J=6.2 \mathrm{~Hz}, 2 \mathrm{H}), 2.86$ $(\mathrm{t}, J=6.2 \mathrm{~Hz}, 2 \mathrm{H}), 2.66(\mathrm{t}, J=7.3 \mathrm{~Hz}, 2 \mathrm{H}), 2.00-1.90(\mathrm{~m}, 2 \mathrm{H}), 1.83 \& 1.80(\mathrm{dt}, J=18.3,7.1 \mathrm{~Hz}, 2 \mathrm{H}), 1.32$ $(\mathrm{t}, J=7.1 \mathrm{~Hz}, 6 \mathrm{H}) ;{ }^{13} \mathrm{C} \mathrm{NMR}\left(\mathrm{CDCl}_{3}\right) \delta 177.2,173.7,62.4,47.9,29.4,27.4,22.9,22.7,21.9,19.1,16.4$; ESI-MS (30eV): $m / z 661.14[2 \mathrm{M}+\mathrm{K}]^{+}, 645.14[2 \mathrm{M}+\mathrm{Na}]^{+}, 350.37[\mathrm{M}+\mathrm{K}]^{+}, 334.43[\mathrm{M}+\mathrm{Na}]^{+}$.

Diethyl (3-(4-(4-(7-chloroquinolin-4-yl)piperazin-1-yl)-N-hydroxy-4-oxobutanamido) propyl) phosphonate (19): To a solution of acid 47 (32 mg, 0,1 mmol) and 2-(1Hbenzotriazol-1-yl)-1, 1,3,3-tetramethyluronium hexafluorophosphate (HBTU) $(42 \mathrm{mg}, 0.1 \mathrm{mmol})$ in $\mathrm{CHCl}_{3}(0.2 \mathrm{~mL})$, amine 44 $(25 \mathrm{mg}, 0.1 \mathrm{mmol})$ and DIPEA $(30 \mu \mathrm{L}, 0.15 \mathrm{mmol})$ were added at ambient temperature. After $2 \mathrm{~h}$, the mixture was evaporated under reduced pressure and the residue thus obtained subjected to FCC providing the conjugate 19; Orange oil (32 mg, 60\%); $\mathrm{R}_{\mathrm{f}}\left(\mathrm{CHCl}_{3} / \mathrm{MeOH} 95: 5\right): 0.12 ;{ }^{1} \mathrm{H} \mathrm{NMR}\left(\mathrm{CDCl}_{3}\right) \delta$ $9.82(\mathrm{~s}, 1 \mathrm{H}), 8.75(\mathrm{~d}, J=5.0 \mathrm{~Hz}, 1 \mathrm{H}), 8.07(\mathrm{~d}, J=2.2 \mathrm{~Hz}, 1 \mathrm{H}), 7.95(\mathrm{~d}, J=9.0 \mathrm{~Hz}, 1 \mathrm{H}), 7.47(\mathrm{dd}, J=9.0$, $2.1 \mathrm{~Hz}, 1 \mathrm{H}), 6.85(\mathrm{~d}, J=5.0 \mathrm{~Hz}, 1 \mathrm{H}), 4.14-4.05(\mathrm{~m}, 4 \mathrm{H}), 3.90(\mathrm{~s}, 2 \mathrm{H}), 3.83-3.78(\mathrm{~m}, 2 \mathrm{H}), 3.75(\mathrm{t}, J=6.1 \mathrm{~Hz}$, $2 \mathrm{H}), 3.25-3.16(\mathrm{~m}, 4 \mathrm{H}), 2.88(\mathrm{t}, J=6.4 \mathrm{~Hz}, 1 \mathrm{H}), 2.77(\mathrm{t}, J=6.4 \mathrm{~Hz}, 1 \mathrm{H}), 2.03-1.90(\mathrm{~m}, 2 \mathrm{H}), 1.80(\mathrm{dt}, J=18.4$, $7.0 \mathrm{~Hz}, 4 \mathrm{H}), 1.32(\mathrm{t}, J=7.1 \mathrm{~Hz}, 6 \mathrm{H}) ;{ }^{13} \mathrm{C} \mathrm{NMR}\left(\mathrm{CDCl}_{3}\right) \delta 173.2,171.3,156.4,151.9,150.1,135.2,129.0$, 
126.7, 124.7, 121.8, 109.4, 62.0, 52.1, 47.6, 45.5, 41.8, 29.0, 27.2, 22.8, 21.9, 19.3, 16.4; HRMS (ESI/Q-TOF): $\mathrm{m} / \mathrm{z} 541.1997[\mathrm{M}+\mathrm{H}]^{+}$; for the compound $\mathrm{C}_{24} \mathrm{H}_{34} \mathrm{ClN}_{4} \mathrm{O}_{6} \mathrm{P}$ requires 541.1977.

4-(((Tert-butoxycarbonyl)oxy)(3-(diethoxy-phosphoryl)propyl)amino)-4-oxobutanoic acid (48): To a solution of $47(55 \mathrm{mg}, 0.176 \mathrm{mmol})$ in $\mathrm{CH}_{2} \mathrm{Cl}_{2}(5.5 \mathrm{~mL})$, catalytic amount of DMAP, $\mathrm{Et}_{3} \mathrm{~N}(25 \mu \mathrm{L}$, $0.176 \mathrm{mmol})$, and di-tert-butyl-dicarbonate $(38 \mathrm{mg}, 0.176 \mathrm{mmol})$ were added and the reaction mixture was stirred overnight at ambient temperature. It was then diluted with DCM and washed with pre-cooled $5 \%$ aqueous citric acid, water, and brine. The organic layer was dried over $\mathrm{Na}_{2} \mathrm{SO}_{4}$, filtered, and evaporated to dryness under reduced pressure. The residue thus obtained was subjected to FCC, affording 48 as yellow oil $(21.7 \mathrm{mg}, 30 \%) ; \mathrm{R}_{\mathrm{f}}\left(\mathrm{CHCl}_{3} / \mathrm{MeOH} 95: 5\right): 0.15 ;{ }^{1} \mathrm{H} \mathrm{NMR}\left(\mathrm{CDCl}_{3}\right) \delta 4.15-4.02$ $(\mathrm{m}, 4 \mathrm{H}), 3.79(\mathrm{t}, J=6.3 \mathrm{~Hz}, 2 \mathrm{H}), 2.67(\mathrm{~d}, J=6.2 \mathrm{~Hz}, 2 \mathrm{H}), 2.62(\mathrm{~d}, J=4.1 \mathrm{~Hz}, 2 \mathrm{H}), 1.90-1.84(\mathrm{~m}, 2 \mathrm{H})$, $1.83-1.75(\mathrm{~m}, 2 \mathrm{H}), 1.54(\mathrm{~s}, 9 \mathrm{H}), 1.31(\mathrm{t}, J=7.1 \mathrm{~Hz}, 6 \mathrm{H}) ;{ }^{13} \mathrm{C} \mathrm{NMR}\left(\mathrm{CDCl}_{3}\right) \delta 175.1,61.8,61.7,28.4,27.6$, $16.4 ;{ }^{31} \mathrm{P} \mathrm{NMR}\left(\mathrm{CDCl}_{3}\right) \delta 34.18$.

Diethyl (3-(N-((tert-butoxycarbonyl)oxy)-4-((2-((7-chloroquinolin-4-yl)amino)ethyl) amino)-4oxobutanamido)propyl)phosphonate (49): To a solution of acid $48(13 \mathrm{mg}, 0.03 \mathrm{mmol})$ and HBTU $(13 \mathrm{mg}, 0.033 \mathrm{mmol})$ in $\mathrm{CHCl}_{3} / \mathrm{DMF} 5: 1(0.3 \mathrm{~mL})$, amine $45(7 \mathrm{mg}, 0.03 \mathrm{mmol})$, and $\mathrm{Et}_{3} \mathrm{~N}(7 \mu \mathrm{L}$, $0.045 \mathrm{mmol}$ ) were added. After $4 \mathrm{~h}$, the reaction mixture was diluted with DCM, washed with pre-cooled $5 \%$ aqueous citric acid, water, $5 \%$ aqueous $\mathrm{NaHCO}_{3}$, water, and brine. The organic layer was dried over $\mathrm{Na}_{2} \mathrm{SO}_{4}$, filtered, and evaporated to dryness under reduced pressure. The residue thus obtained was subjected to FCC, affording the corresponding pure conjugate 49 as yellow oil $(9.2 \mathrm{mg}$, $50 \%) ; \mathrm{R}_{\mathrm{f}}\left(\mathrm{CHCl}_{3} / \mathrm{MeOH} 95: 5\right): 0.18 ;{ }^{1} \mathrm{H} \mathrm{NMR}\left(\mathrm{CDCl}_{3}\right) \delta 8.41(\mathrm{~d}, J=5.6 \mathrm{~Hz}, 1 \mathrm{H}), 7.93(\mathrm{~d}, J=2.0 \mathrm{~Hz}, 1 \mathrm{H})$, $7.91(\mathrm{~s}, 1 \mathrm{H}), 7.39(\mathrm{dd}, J=8.9,2.0 \mathrm{~Hz}, 1 \mathrm{H}), 7.16(\mathrm{~s}, 1 \mathrm{H}), 7.05(\mathrm{~s}, 1 \mathrm{H}), 6.28(\mathrm{~d}, J=5.7 \mathrm{~Hz}, 1 \mathrm{H}), 4.13-4.01(\mathrm{~m}$, $4 \mathrm{H}), 3.67(\mathrm{~s}, 4 \mathrm{H}), 3.44-3.38(\mathrm{~m}, 2 \mathrm{H}), 2.69(\mathrm{~s}, 2 \mathrm{H}), 2.56(\mathrm{~s}, 2 \mathrm{H}), 1.83-1.75(\mathrm{~m}, 2 \mathrm{H}), 1.74(\mathrm{~d}, J=13.1 \mathrm{~Hz}, 2 \mathrm{H})$, $1.51(\mathrm{~s}, 9 \mathrm{H}), 1.30(\mathrm{t}, J=7.1 \mathrm{~Hz}, 6 \mathrm{H}) ;{ }^{13} \mathrm{C} \mathrm{NMR}\left(\mathrm{CDCl}_{3}\right) \delta 174.7,151.3,149.9,135.8,126.5,125.8,122.8$, 117.0, 98.0, 61.7, 45.1, 38.6, 27.5, 20.2, 16.4; ESI-MS (30eV): $\mathrm{m} / \mathrm{z} 1251.76[2 \mathrm{M}+\mathrm{Na}]^{+}, 653.26\left[\mathrm{M}+\mathrm{K}^{+}\right.$, $637.49[\mathrm{M}+\mathrm{Na}]^{+}, 615.52[\mathrm{M}+\mathrm{H}]^{+}$.

7-Chloro- $\mathrm{N}-(2-(4-((3-($ diethoxyphosphoryl)propyl)(hydroxy)amino)-4oxobutanamido) ethyl) quinolin-4-aminium 2,2,2-trifluoroacetate (20): To an ice-cold solution of 49 (6 mg, $0.01 \mathrm{mmol}$ ) in $\mathrm{CH}_{2} \mathrm{Cl}_{2}(0.4 \mathrm{~mL})$, trifluoroacetic acid (TFA) $(12 \mu \mathrm{L})$ was added and the reaction mixture was stirred overnight at ambient temperature. Then, volatile components were evaporated under vacuum and the oily residue thus obtained was subjected to FCC, affording pure conjugate 20. Colorless oil (3.8 mg, $60 \%) ; \mathrm{R}_{\mathrm{f}}\left(\mathrm{CHCl}_{3} / \mathrm{MeOH} 85: 15\right): 0.3 ;{ }^{1} \mathrm{H} \mathrm{NMR}\left(\mathrm{CDCl}_{3}\right) \delta 9.15(\mathrm{~s}, 1 \mathrm{H}), 8.28(\mathrm{~d}, J=6.6 \mathrm{~Hz}, 1 \mathrm{H}), 8.15(\mathrm{~d}$, $J=9.0 \mathrm{~Hz}, 1 \mathrm{H}), 7.93(\mathrm{~s}, 2 \mathrm{H}), 7.45(\mathrm{~d}, J=8.9 \mathrm{~Hz}, 1 \mathrm{H}), 6.40(\mathrm{~d}, J=6.8 \mathrm{~Hz}, 1 \mathrm{H}), 4.13-4.02(\mathrm{~m}, 4 \mathrm{H}), 3.69-3.61$ $(\mathrm{m}, 4 \mathrm{H}), 3.53(\mathrm{~s}, 2 \mathrm{H}), 2.89(\mathrm{t}, J=6.4 \mathrm{~Hz}, 2 \mathrm{H}), 2.59(\mathrm{t}, J=6.1 \mathrm{~Hz}, 2 \mathrm{H}), 1.97-1.88(\mathrm{~m}, 2 \mathrm{H}), 1,81-1.75(\mathrm{~m}, 23 \mathrm{H})$, $1.32(\mathrm{t}, J=7.0 \mathrm{~Hz}, 6 \mathrm{H}) ;{ }^{13} \mathrm{C}$ NMR $\left(\mathrm{CDCl}_{3}\right) \delta 176.0,173.5,155.6,142.7,139.8,138.7,127.9,124.4,120.0$, 115.3, 97.5, 62.3, 47.9, 45.4, 38.1, 31.2, 29.7, 28.3, 22,6 21.8, 19.2, 16.4; HRMS (ESI/Q-TOF): m/z 537.1649 $[\mathrm{M}+\mathrm{Na}]^{+}$; for the compound $\mathrm{C}_{22} \mathrm{H}_{32} \mathrm{ClN}_{4} \mathrm{O}_{6} \mathrm{P}$ requires 537.1640.

\subsubsection{Synthesis of FSM-ART Conjugates 21-23}

Diethyl (3-(N-(benzyloxy)-3-((3S,5aS,6R,8aS, 9R,10R,12R)-3,6,9-trimethyldecahydro-12H-3,12 epoxy [1,2] dioxepino [4,3-i]isochromen-10-yl)propanamido) propyl) phosphonate (51): To a solution of artemisinin derivative $50(25 \mathrm{mg}, 0.07 \mathrm{mmol})$ in DCM $(0.47 \mathrm{~mL})$, HBTU $(29 \mathrm{mg}, 0.077 \mathrm{mmol})$ and $\mathrm{Et}_{3} \mathrm{~N}(15 \mu \mathrm{L}, 0.105 \mathrm{mmol})$ were added. The reaction mixture was stirred overnight at ambient temperature. Subsequently, it was diluted with $\mathrm{CH}_{2} \mathrm{Cl}_{2}$, washed with pre-cooled $5 \%$ aqueous citric acid, water, $5 \%$ aqueous $\mathrm{NaHCO}_{3}$, water, and brine. The organic layer was dried over $\mathrm{Na}_{2} \mathrm{SO}_{4}$, filtered, and evaporated to dryness under reduced pressure. The residue thus obtained was subjected to FCC, affording conjugate 51 as yellow oil $(22 \mathrm{mg}, 50 \%) ; \mathrm{R}_{\mathrm{f}}(\mathrm{AcOEt}): 0.17 ;{ }^{1} \mathrm{H} \mathrm{NMR}\left(\mathrm{CDCl}_{3}\right) \delta 7.44-7.39(\mathrm{~m}$, $2 \mathrm{H}), 7.38-7.33(\mathrm{~m}, 3 \mathrm{H}), 5.29(\mathrm{~s}, 1 \mathrm{H}), 4.85(\mathrm{~s}, 2 \mathrm{H}), 4.12-4.03(\mathrm{~m}, 4 \mathrm{H}), 3.78-3.65(\mathrm{~m}, 2 \mathrm{H}), 2.80(\mathrm{~s}, 1 \mathrm{H})$, 2.76-2.71 (m, 1H), 2.55-2.47 (m, 1H), $2.33(\mathrm{td}, J=14.0,3.9 \mathrm{~Hz}, 1 \mathrm{H}), 2.04-1.99(\mathrm{~m}, 1 \mathrm{H}), 1.98-1.91(\mathrm{~m}, 2 \mathrm{H})$, $1.91-1.86(\mathrm{~m}, 1 \mathrm{H}), 1.83-1.78(\mathrm{~m}, 1 \mathrm{H}), 1.77-1.69(\mathrm{~m}, 3 \mathrm{H}), 1.68-1.62(\mathrm{~m}, 4 \mathrm{H}), 1.59-1.53(\mathrm{~m}, 1 \mathrm{H}), 1.50-1.40$ $(\mathrm{m}, 2 \mathrm{H}), 1.39(\mathrm{~s}, 3 \mathrm{H}), 1.30(\mathrm{t}, J=7.1 \mathrm{~Hz}, 6 \mathrm{H}), 1.27-1.20(\mathrm{~m}, 2 \mathrm{H}), 0.94(\mathrm{~d}, J=6.1 \mathrm{~Hz}, 3 \mathrm{H}), 0.88(\mathrm{~d}, J=7.5 \mathrm{~Hz}$, 
$3 \mathrm{H}) ;{ }^{13} \mathrm{C} \mathrm{NMR}\left(\mathrm{CDCl}_{3}\right) \delta 129.4,128.9,128.7,103.4,88.6,81.2,75.9,61.6,52.5,44.6,37.4,36.6,34.5,30.2$, 26.2, 24.9, 24.7, 24.0, 20.2, 16.5, 13.3; ESI-MS (30eV): $\mathrm{m} / \mathrm{z} 1285.61[2 \mathrm{M}+\mathrm{K}]^{+}, 1269.36[2 \mathrm{M}+\mathrm{Na}]^{+}, 662.46$ $[\mathrm{M}+\mathrm{K}]^{+}, 646.46[\mathrm{M}+\mathrm{Na}]^{+}$.

Diethyl (3-(N-hydroxy-3-((3S,5aS,6R,8aS,9R,10R,12R)-3,6,9-trimethyldecahydro-12H-3, 12-epoxy [1,2]dioxepino[4,3-i]isochromen-10-yl)propanamido)propyl)phosphonate (21): A solution of conjugate $51(20 \mathrm{mg}, 0.032 \mathrm{mmol})$ in methanol $(3 \mathrm{~mL})$ was subjected to hydrogenolysis over $10 \% \mathrm{Pd} / \mathrm{C}(5 \mathrm{mg})$ at ambient temperature for $4 \mathrm{~h}$. Thus, the reaction mixture was filtered through Celite and the filter cake was washed several times with methanol. After evaporation of the solvent to dryness under reduced pressure, the residue was subjected to FCC, affording pure 21; Orange oil (15 mg, 90\%); $\mathrm{R}_{\mathrm{f}}\left(\mathrm{DCM} / \mathrm{MeOH}\right.$ 95:5): 0.35; ${ }^{1} \mathrm{H}$ NMR $\left(\mathrm{CDCl}_{3}\right) \delta 8.52(\mathrm{br} \mathrm{s}, 1 \mathrm{H}), 8.08(\mathrm{~s}, 1 \mathrm{H}), 5.28(\mathrm{~s}, 1 \mathrm{H}), 4.10-4.01(\mathrm{~m}$, $4 \mathrm{H}), 3.87(\mathrm{dt}, J=13.5,6.6 \mathrm{~Hz}, 1 \mathrm{H}), 3.74-3.69(\mathrm{~m}, 1 \mathrm{H}), 3.57-3.50(\mathrm{~m}, 1 \mathrm{H}), 2.69-2.63(\mathrm{~m}, 1 \mathrm{H}), 2.57-2.47(\mathrm{~m}$, 2H), $2.11(\mathrm{~s}, 2 \mathrm{H}) 1.99-1.89(\mathrm{~m}, 4 \mathrm{H}), 1.85-1.74(\mathrm{~m}, 7 \mathrm{H}), 1.51(\mathrm{~s}, 3 \mathrm{H}), 1.431-1.28(\mathrm{~m}, 7 \mathrm{H}), 1.05(\mathrm{~d}, J=6.3 \mathrm{~Hz}$, $3 \mathrm{H}), 0.96(\mathrm{~d}, J=6.7 \mathrm{~Hz}, 3 \mathrm{H}) ;{ }^{13} \mathrm{C} \mathrm{NMR}\left(\mathrm{CDCl}_{3}\right) \delta 175.0,161.0,107.6,97.2,82.6,69.3,61.7,57.4,54.3$, 48.0, 45.2, 41.4, 40.0, 35.5, 34.5, 27.8, 25.1, 23.4, 22.0, 20.5, 19.7, 18.8, 16.4, 12.5, 11.9; HRMS (ESI/Q-TOF): $m / z 556.2650[\mathrm{M}+\mathrm{Na}]^{+}$; for the compound $\mathrm{C}_{25} \mathrm{H}_{44} \mathrm{NO}_{9} \mathrm{P}$ requires 556.2646.

General procedure for the synthesis of FSD-polyamine conjugates. To a solution of $42(60 \mathrm{mg}$, $0.15 \mathrm{mmol})$ and $\mathrm{HBTU}(62 \mathrm{mg}, 0.165 \mathrm{mmol})$ in $\mathrm{CHCl}_{3}(300 \mu \mathrm{L})$, the suitable protected spermidine 52 (94 mg, $0.15 \mathrm{mmol}$ ) or homospermidine $53\left(96 \mathrm{mg}, 0.15 \mathrm{mmol}\right.$ ) and $\mathrm{Et}_{3} \mathrm{~N}(32 \mu \mathrm{L}, 0.225 \mathrm{mmol}$ ) were added. After $7-12 \mathrm{~h}$, the mixture was diluted with $\mathrm{CHCl}_{3}$ and washed with pre-cooled $5 \%$ aqueous citric acid, water, $5 \%$ aqueous $\mathrm{NaHCO}_{3}$, water, and brine. The organic layer was dried over $\mathrm{Na}_{2} \mathrm{SO}_{4}$, filtered and evaporated to dryness under reduced pressure. The residues thus obtained were subjected to FCC, affording the corresponding conjugates 54 and 55.

Diethyl (3-(N-(benzyloxy)-4-oxo-4-((4-(tritylamino)butyl)(3-(tritylamino)propyl)amino)butanamido) propyl) phosphonate (54): Reaction time: 7h; White foam (109 mg, 72\%); $\mathrm{R}_{\mathrm{f}}(\mathrm{AcOEt}): 0.2 ;{ }^{1} \mathrm{H} \mathrm{NMR}\left(\mathrm{CDCl}_{3}\right) \delta$ 7.50-7.42 (m, 12H), 7.42-7.32 (m, 5H), 7.31-7.21 (m, 12H), 7.20-7.12 (m, 6H), $4.91(\mathrm{~s}, 1 \mathrm{H}), 4.88(\mathrm{~s}, 1 \mathrm{H})$, 4.10-4.02 (m, 4H), 3.73-3.64 (m, 2H), $3.38(\mathrm{t}, J=7.1 \mathrm{~Hz}, 1 \mathrm{H}), 3.33(\mathrm{t}, J=7.7 \mathrm{~Hz} 1 \mathrm{H}), 3.25(\mathrm{t}, J=7.1 \mathrm{~Hz}$, $1 \mathrm{H}), 3.14(\mathrm{t}, J=7.6 \mathrm{~Hz}, 1 \mathrm{H}), 2.76(\mathrm{~s}, 1 \mathrm{H}), 2.60(\mathrm{t}, J=6.0 \mathrm{~Hz}, 1 \mathrm{H}), 2.51(\mathrm{t}, J=5.9 \mathrm{~Hz}, 1 \mathrm{H}), 2.18-2.10(\mathrm{~m}, 3 \mathrm{H})$, 2.08-2.05 (m, 1H), 1.97-1.87 (m, 2H), $1.74(\mathrm{~s}, 3 \mathrm{H}), 1.72-1.65(\mathrm{~m}, 2 \mathrm{H}), 1.60-1.55(\mathrm{~m}, 1 \mathrm{H}), 1.53-1.42(\mathrm{~m}, 3 \mathrm{H})$, $1.30-1.25(\mathrm{~m}, 6 \mathrm{H}) ;{ }^{13} \mathrm{C} \mathrm{NMR}\left(\mathrm{CDCl}_{3}\right) \delta 171.2,146.2,146.1,145.9,134.5,129.1,128.8,128.6,128.5,127.8$, $127.7,126.3,126.2,126.1,76.4,70.8,61.5,60.4,47.5,46.2,43.7,43.5,43.3,41.3,40.9,38.6,30.3,28.7,28.4$, 28.1, 27.6, 27.3, 26.7, 25.8, 23.5, 22.5, 21.0, 20.2, 16.4, 14.2; ESI-MS (30eV): $\mathrm{m} / z 1035.75[\mathrm{M}+\mathrm{Na}]^{+}, 1013.39$ $[\mathrm{M}+\mathrm{H}]^{+}, 301.48\left[\mathrm{M}-\mathrm{C}_{49} \mathrm{H}_{50} \mathrm{H}_{3} \mathrm{O}_{2}\right]^{+}, 243.28[\mathrm{Trt}]^{+}$.

Diethyl (3-(N-(benzyloxy)-4-(bis(4-(tritylamino)butyl)amino)-4-oxobutanamido) propyl) phosphonate (55): Yellow pale foam (148 mg, 96\%); $\mathrm{R}_{\mathrm{f}}\left(\mathrm{AcOEt} / \mathrm{Et}_{3} \mathrm{~N} 1 \%\right): 0.18 ;{ }^{1} \mathrm{H} \mathrm{NMR}\left(\mathrm{CDCl}_{3}\right) \delta 7.49-7.41(\mathrm{~m}, 9 \mathrm{H})$, 7.40-7.32 (m, 6H), 7.30-7.21 (m, 12H), 7.19-7.12 (m, 5H), $4.90(\mathrm{~s}, 1 \mathrm{H}), 4.87(\mathrm{~s}, 1 \mathrm{H}), 4.15-4.05(\mathrm{~m}, 6 \mathrm{H})$, $3.70(\mathrm{dt}, J=14.0,7.0 \mathrm{~Hz}, 2 \mathrm{H}), 3.22(\mathrm{dt}, J=15.0,7.1 \mathrm{~Hz}, 2 \mathrm{H}), 3.22-3.17(\mathrm{~m}, 1 \mathrm{H}), 2.82-2.72(\mathrm{~m}, 2 \mathrm{H}), 2.55$ $(\mathrm{t}, J=6.4 \mathrm{~Hz}, 1 \mathrm{H}), 2.12(\mathrm{dt}, J=14.3,7.0 \mathrm{~Hz}, 2 \mathrm{H}), 1.97-1.78(\mathrm{~m}, 4 \mathrm{H}), 1.74-1.64(\mathrm{~m}, 4 \mathrm{H}), 1.60-1.41(\mathrm{~m}, 7 \mathrm{H})$, 1.34-1.24 (m, 10H); ${ }^{13} \mathrm{C} \mathrm{NMR}\left(\mathrm{CDCl}_{3}\right) \delta 171.2,146.2,146.1,129.2,128.6,127.8,127.7,126.2,70.2,61.5$, 60.6, 59.2, 47.7, 46.0, 43.4, 28.7, 28.4, 28.2, 27.7, 27.4, 26.7, 25.7, 24.0, 23.5, 23.1, 22.5, 20.3, 16.4, 14.2.

Trityl-deprotection of conjugates 54 and 55 . To an ice-cold solution of 54 or $55(0.12 \mathrm{mmol})$ in DCM $(1.0 \mathrm{~mL})$, TFE $(50 \mu \mathrm{L}, 0.65 \mathrm{mmol})$ and TFA $(50 \mu \mathrm{L}, 0.65 \mathrm{mmol})$ were added. The reaction mixture was stirred at ambient temperature for $6 \mathrm{~h}$. Volatile components were evaporated under vacuo, and the oily residue was triturated with $\mathrm{Et}_{2} \mathrm{O} / \mathrm{Hex}$ and refrigerated overnight. The corresponding trifluoroacetate salts 56 and 57 were received after decanting of the solvents.

4-(N-(3-ammoniopropyl)-4-((benzyloxy)(3-(diethoxyphosphoryl)propyl)amino)-4-oxobutanamido)butan-1aminium 2,2,2-trifluoroacetate (56): Yellow oil (82 mg, 90\%); ${ }^{1} \mathrm{H}$ NMR (MeOD): $\delta 7.49-7.45(\mathrm{~m}, 2 \mathrm{H})$, 7.44-7.39 (m, 3H), $4.97($ br s, $2 \mathrm{H}), 4.13-4.05(\mathrm{~m}, 4 \mathrm{H}), 3.78(\mathrm{t}, J=6.5 \mathrm{~Hz}, 2 \mathrm{H}), 3.52-3.47(\mathrm{~m}, 3 \mathrm{H}), 3.45$ $(\mathrm{t}, J=7.4 \mathrm{~Hz}, 1 \mathrm{H}), 3.03-2.97(\mathrm{~m}, 2 \mathrm{H}), 2.90(\mathrm{t}, J=7.0 \mathrm{~Hz}, 2 \mathrm{H}), 2.82(\mathrm{br} \mathrm{s}, 2 \mathrm{H}), 2.71-2.65(\mathrm{~m}, 2 \mathrm{H}), 1.94-1.86$ 
$(\mathrm{m}, 4 \mathrm{H}), 1.85-1.68(\mathrm{~m}, 6 \mathrm{H}), 1.65-1.61(\mathrm{~m}, 1 \mathrm{H}), 1.31(\mathrm{t}, J=7.1 \mathrm{~Hz}, 6 \mathrm{H}) ;{ }^{13} \mathrm{C}$ NMR $(\mathrm{MeOD}) \delta$ 174.0, 172.8, 134.7, 129.2, 128.7, 128.3, 75.9, 65.5, 61.9, 44.4, 41.9, 39.0, 36.8, 36.5, 30.9, 27.1, 26.8, 26.3, 25.4, 25.2, 24.4, 24.2, 24.0, 22.2, 21.3, 19.7, 15.3, 15.3, 14.0, 12.9; HRMS (ESI/Q-TOF): $\mathrm{m} / \mathrm{z} 461.2503$ [M + Na] ${ }^{+}$; for the compound $\mathrm{C}_{25} \mathrm{H}_{45} \mathrm{~N}_{4} \mathrm{O}_{6} \mathrm{P}$ requires 461.2499 .

4,4'-((4-((Benzyloxy)(3-(diethoxyphosphoryl)propyl)amino)-4-oxobutanoyl)azanediyl) bis(butan-1-aminium) 2,2,2-trifluoroacetate (57): Yellow oil (83 mg, 90\%); ${ }^{1} \mathrm{H}$ NMR (MeOD): $\delta$ 7.48-7.44 (m, 2H), 7.42-7.36 $(\mathrm{m}, 3 \mathrm{H}), 4.96(\mathrm{~s}, 2 \mathrm{H}), 4.11-4.04(\mathrm{~m}, 4 \mathrm{H}), 3.76(\mathrm{t}, J=6.6 \mathrm{~Hz}, 2 \mathrm{H}), 3.41(\mathrm{t}, J=6.9 \mathrm{~Hz}, 2 \mathrm{H}), 3.37(\mathrm{br} \mathrm{s}, 2 \mathrm{H})$, $3.31-3.28(\mathrm{~m}, 2 \mathrm{H}), 2.98(\mathrm{t}, J=6.9 \mathrm{~Hz}, 2 \mathrm{H}), 2.94(\mathrm{br} \mathrm{s}, 2 \mathrm{H}), 2.80(\mathrm{~s}, 1 \mathrm{H}), 2.79(\mathrm{br} \mathrm{s}, 1 \mathrm{H}), 2.67-2.63(\mathrm{~m}, 2 \mathrm{H})$, $1.93-1.86(\mathrm{~m}, 2 \mathrm{H}), 1.83-1.76(\mathrm{~m}, 2 \mathrm{H}), 1.75-1.66(\mathrm{~m}, 4 \mathrm{H}), 1.62(\mathrm{br} \mathrm{s}, 4 \mathrm{H}), 1.30(\mathrm{t}, J=7.1 \mathrm{~Hz}, 6 \mathrm{H}) ;{ }^{13} \mathrm{C} \mathrm{NMR}$ (MeOD) $\delta 172.7,161.2,160.9,160.7,160.5,134.7,129.2,128.6,128.3,127.9,127.2,126.6,119.0,117.4,115.5$, 112.5, 75.9, 61.9, 46.8, 44.6, 39.0, 27.0, 25.2, 24.4, 24.3, 24.0, 22.2, 21.3, 19.7, 15.3; HRMS (ESI/Q-TOF): $m / z$ $453.2848[\mathrm{M}+\mathrm{H}]^{+}$; for the compound $\mathrm{C}_{26} \mathrm{H}_{47} \mathrm{~N}_{4} \mathrm{O}_{6} \mathrm{P}$ requires 453.2836 .

General procedure for the synthesis of ART-FSD conjugates 58 \& 59. To a solution of $50(20 \mathrm{mg}$, $0.06 \mathrm{mmol})$ and HBTU $(25 \mathrm{mg}, 0.066 \mathrm{mmol})$ in $\mathrm{CHCl}_{3}(300 \mu \mathrm{L})$, compound $56(22 \mathrm{mg}, 0.03 \mathrm{mmol})$ or $57(21 \mathrm{mg}, 0.03 \mathrm{mmol})$, and $\mathrm{Et}_{3} \mathrm{~N}(20 \mu \mathrm{L}, 0.135 \mathrm{mmol})$ were added. After $12 \mathrm{~h}$, the mixture was diluted with $\mathrm{CHCl}_{3}$ and washed with pre-cooled $5 \%$ aqueous citric acid, water, $5 \%$ aqueous $\mathrm{NaHCO}_{3}$, water, and brine. The organic layer was dried over $\mathrm{Na}_{2} \mathrm{SO}_{4}$, filtered, and evaporated to dryness under reduced pressure. The residues thus obtained were subjected to FCC, affording the corresponding conjugates 58 and 59.

Diethyl(3-(N-(benzyloxy)-4-oxo-4-((4-(3-((3S,5aS,6R,8aS,9R,10R,12R)-3,6,9-trimethyldecahydro-12H-3, 12-epoxy[1,2]dioxepino[4,3-i]isochromen-10-yl)propanamido)butyl)(3-(3-((3S,5aS,6R,8aS,9R,10R,12R)-3,6, 9-trimethyldecahydro-12H-3,12-epoxy[1,2]dioxepino[4,3-i]isochromen-10-yl)propanamido)propyl)amino) butanamido)propyl)phosphonate (58): Yellow oil (18 mg, 50\%); $\mathrm{R}_{\mathrm{f}}\left(\mathrm{CHCl}_{3} / \mathrm{MeOH} 95: 5\right): 0.3 ;{ }^{1} \mathrm{H} \mathrm{NMR}$ $\left(\mathrm{CDCl}_{3}\right) \delta$ 7.43-7.35 (m, 5H), $5.29(\mathrm{~s}, 2 \mathrm{H}), 4.92(\mathrm{~s}, 2 \mathrm{H}), 4.12-3.98(\mathrm{~m}, 6 \mathrm{H}), 3.70(\mathrm{~s}, 2 \mathrm{H}), 3.44-3.35(\mathrm{~m}, 2 \mathrm{H})$, 3.33-3.23 (m, 5H), 3.20-3.13 (m, 2H), $2.81(\mathrm{~s}, 2 \mathrm{H}), 2.74-2.68(\mathrm{~m}, 2 \mathrm{H}), 2.66-2.57(\mathrm{~m}, 2 \mathrm{H}), 2.51-2.38(\mathrm{~m}, 2 \mathrm{H})$, 2.36-2.24 (m, 4H), 2.05-1.98 (m, 3H), 1.96-1.85 (m, 6H), $1.77(\mathrm{~s}, 8 \mathrm{H}), 1.70-1.60(\mathrm{~m}, 7 \mathrm{H}), 1.58-1.51(\mathrm{~m}$, $4 \mathrm{H}), 1.48-1.43(\mathrm{~m}, 3 \mathrm{H}), 1.41-1.35(\mathrm{~m}, 7 \mathrm{H}), 1.29(\mathrm{t}, J=7.0 \mathrm{~Hz}, 6 \mathrm{H}), 1.26-1.20(\mathrm{~m}, 3 \mathrm{H}), 0.94(\mathrm{t}, J=5.8 \mathrm{~Hz}$, 6H), $0.87(\mathrm{t}, J=7.3 \mathrm{~Hz}, 6 \mathrm{H}) ;{ }^{13} \mathrm{C} \mathrm{NMR}\left(\mathrm{CDCl}_{3}\right) \delta 173.1,173.0,172.2,129.2,128.9,128.7,103.4,88.7,81.2$, 61.6, 52.5, 47.3, 44.6, 44.5, 43.0, 38.9, 37.3, 36.5, 36.2, 34.6, 34.4, 30.2, 27.4, 27.0, 26.2, 24.9, 24.6, 20.2, 16.5, 13.2; ESI-MS (30eV): $\mathrm{m} / \mathrm{z} 1211.62[\mathrm{M}+\mathrm{K}]^{+}, 1195.80[\mathrm{M}+\mathrm{Na}]^{+}$.

Diethyl(3-(N-(benzyloxy)-4-(bis(4-(3-((3S,5aS,6R,8aS,9R,10R,12R)-3,6,9-trimethyldecahydro-12H-3,12-epoxy [1,2]dioxepino[4,3-i]isochromen-10-yl)propanamido)butyl)amino)-4-oxobutanamido)propyl)phosphonate (59): White foam (18 mg, 50\%), $\mathrm{R}_{\mathrm{f}}\left(\mathrm{CHCl}_{3} / \mathrm{MeOH} 95: 5\right): 0.3 ;{ }^{1} \mathrm{H} \mathrm{NMR}\left(\mathrm{CDCl}_{3}\right) \delta$ 7.44-7.32 (m, 5H), $6.32(\mathrm{~s}$, $1 \mathrm{H}), 6.21(\mathrm{~s}, 1 \mathrm{H}), 5.28(\mathrm{~s}, 2 \mathrm{H}), 4.91(\mathrm{~s}, 2 \mathrm{H}), 4.13-3.98(\mathrm{~m}, 6 \mathrm{H}), 3.69(\mathrm{~s}, 2 \mathrm{H}), 3.36-3.19(\mathrm{~m}, 8 \mathrm{H}), 2.80(\mathrm{~s}, 4 \mathrm{H})$, 2.74-2.67 (m, 2H), $2.60(\mathrm{~s}, 2 \mathrm{H}), 2.47-2.40(\mathrm{~m}, 2 \mathrm{H}), 2.35-2.24(\mathrm{~m}, 4 \mathrm{H}), 2.04-1.97(\mathrm{~m}, 2 \mathrm{H}), 1.95-1.85(\mathrm{~m}$, $8 \mathrm{H}), 1.83-1.77(\mathrm{~m}, 4 \mathrm{H}), 1.75-1.70(\mathrm{~m}, 2 \mathrm{H}), 1.67-1.60(\mathrm{~m}, 4 \mathrm{H}), 1.58-1.51(\mathrm{~m}, 7 \mathrm{H}), 1.49-1.42(\mathrm{~m}, 4 \mathrm{H}), 1.37$ $(\mathrm{d}, J=3.4 \mathrm{~Hz}, 6 \mathrm{H}), 1.29(\mathrm{t}, J=7.0 \mathrm{~Hz}, 6 \mathrm{H}), 1.25-1.21(\mathrm{~m}, 3 \mathrm{H}), 0.96-0.91(\mathrm{~m}, 6 \mathrm{H}), 0.89-0.83(\mathrm{~m}, 6 \mathrm{H})$; ${ }^{13} \mathrm{C} \mathrm{NMR}\left(\mathrm{CDCl}_{3}\right) \delta 173.1,171.4,134.5,129.2,128.9,128.7,103.4,88.7,81.2,61.6,52.5,47.5,45.6,44.5$, 38.8, 38.6, 37.4, 36.5, 34.5, 34.4, 30.2, 27.6, 27.4, 27.0, 26.7, 26.1, 25.0, 24.8, 24.8, 24.6, 23.4, 22.5, 20.2, 16.5, 13.2; ESI-MS (30eV): $\mathrm{m} / \mathrm{z} 1225.82[\mathrm{M}+\mathrm{K}]^{+}, 1210.29[\mathrm{M}+\mathrm{Na}]^{+}$.

General procedure for the hydrogenolysis of $\mathbf{5 6}-\mathbf{5 9}$. A solution of $\mathbf{5 6}$ or $\mathbf{5 7}$ or $\mathbf{5 8}$ or $\mathbf{5 9}(0.01 \mathrm{mmol})$ in methanol $(3 \mathrm{~mL})$ was subjected to hydrogenolysis over $10 \% \mathrm{Pd} / \mathrm{C}(5 \mathrm{mg})$ at ambient temperature and pressure for $4 \mathrm{~h}-6.5 \mathrm{~h}$. Thus, the reaction mixture was filtered through Celite and the filter cake was washed several times with methanol. After evaporation of the solvent to dryness under reduced pressure, the residues were subjected to FCC, affording the corresponding pure deprotected molecules $24,25,22$, and 23, respectively.

Diethyl(3-(N-hydroxy-4-oxo-4-((4-(3-((3S,5aS,6R,8aS,9R,10R,12R)-3,6,9-trimethyldecahydro-12H-3,12-epoxy [1,2]dioxepino[4,3-i]isochromen-10-yl)propanamido)butyl)(3-(3-((3S,5aS,6R,8aS,9R,10R,12R)-3,6,9- 
trimethyldecahydro-12H-3,12-epoxy[1,2]dioxepino[4,3-i]isochromen-10-yl)propanamido)propyl)amino) butanamido)propyl)phosphonate (22): Yellow oil (6.5 mg, 60\%), $\mathrm{R}_{\mathrm{f}}\left(\mathrm{CHCl}_{3} / \mathrm{MeOH} 97: 3\right)$ : 0.35; ${ }^{1} \mathrm{H} \mathrm{NMR}$ $\left(\mathrm{CDCl}_{3}\right) \delta 9.94$ (br s, 1H), 8.18 (br s, 1H) $5.33(\mathrm{~s}, 2 \mathrm{H}), 4.23-4.07(\mathrm{~m}, 6 \mathrm{H}), 3.79(\mathrm{~s}, 2 \mathrm{H}), 3.49-3.33(\mathrm{~m}, 7 \mathrm{H})$, 3.24-3.19 (s, 3H), 2.89 (br s, 2H), 2.79 (br s, $2 \mathrm{H}), 2.45-2.37(\mathrm{~m}, 3 \mathrm{H}), 2.36-2.27(\mathrm{~m}, 4 \mathrm{H}), 2.21(\mathrm{~s}, 2 \mathrm{H})$, 2.03-1.96 (m, 5H), 1.95-1.90 (m, 4H), 1.88-1.83 (m, 5H), 1.78-1.72 (m, 8H), $1.55(\mathrm{~s}, 5 \mathrm{H}), 1.49(\mathrm{t}, J=7.4 \mathrm{~Hz}$, $3 \mathrm{H}), 1.40(\mathrm{t}, J=6.9 \mathrm{~Hz}, 8 \mathrm{H}), 1.34(\mathrm{~s}, 4 \mathrm{H}), 1.58-1.13(\mathrm{~m}, 2 \mathrm{H}), 1.06-1.02(\mathrm{~m}, 3 \mathrm{H}), 0.99-0.94(\mathrm{~m}, 9 \mathrm{H})$; ${ }^{13} \mathrm{C}$ NMR $\left(\mathrm{CDCl}_{3}\right) \delta$ 213.4, 209.3, 173.7, 160.5, 107.3, 97.4, 82.7, 68.3, 62.2, 54.6, 47.9, 46.3, 45.6, 41.8, 40.8, 39.0, 35.9, 34.9, 34.1, 30.2, 29.9, 27.6, 25.5, 24.1, 24.0, 22.5, 20.8, 20.6, 19.1, 16.8, 12.9, 12.4, 8.9; HRMS (ESI/Q-TOF): $\mathrm{m} / \mathrm{z} 1083.6273[\mathrm{M}+\mathrm{H}]^{+}$; for the compound $\mathrm{C}_{54} \mathrm{H}_{91} \mathrm{~N}_{4} \mathrm{O}_{16} \mathrm{P}$ requires 1083.6240.

Diethyl(3-(4-(bis(4-(3-((3S,5aS,6R,8aS,9R,10R,12R)-3,6,9-trimethyldecahydro-12H-3,12-epoxy[1,2]dioxepino [4,3-i]isochromen-10-yl)propanamido)butyl)amino)-N-hydroxy-4-oxobutanamido)propyl)phosphonate (23): Yellow oil (6.6 mg, 60\%), $\mathrm{R}_{\mathrm{f}}\left(\mathrm{CHCl}_{3} / \mathrm{MeOH} 97: 3\right): 0.35 ;{ }^{1} \mathrm{H} \mathrm{NMR}\left(\mathrm{CDCl}_{3}\right) \delta 9.97(\mathrm{br} \mathrm{s}, 1 \mathrm{H}), 8.09(\mathrm{~s}, 1 \mathrm{H})$ $5.24(\mathrm{~s}, 2 \mathrm{H}), 4.12-4.04(\mathrm{~m}, 6 \mathrm{H}), 3.70(\mathrm{br} \mathrm{s}, 2 \mathrm{H}), 3.31-3.22(\mathrm{~m}, 7 \mathrm{H}), 3.15-3.08(\mathrm{~m}, 2 \mathrm{H}), 2.78-2.69(\mathrm{~m}$, $4 \mathrm{H}), 2.35-2.29(\mathrm{~m}, 3 \mathrm{H}), 2.24-2.18(\mathrm{~m}, 4 \mathrm{H}), 2.12(\mathrm{~s}, 2 \mathrm{H}), 2.08-1.99(\mathrm{~m}, 4 \mathrm{H}), 1.94-1.88(\mathrm{~m}, 7 \mathrm{H}), 1.78-1.74$ $(\mathrm{m}, 4 \mathrm{H}), 1.67-1.64(\mathrm{~m}, 4 \mathrm{H}), 1.62-1.57(\mathrm{~m}, 5 \mathrm{H}), 1.54-1.48(\mathrm{~m}, 5 \mathrm{H}), 1.46(\mathrm{~s}, 7 \mathrm{H}), 1.31(\mathrm{t}, J=6.9 \mathrm{~Hz}, 6 \mathrm{H})$, $1.26-1.14(\mathrm{~m}, 6 \mathrm{H}), 1.05(\mathrm{~d}, J=5.8 \mathrm{~Hz}, 2 \mathrm{H}), 0.96(\mathrm{~d}, J=6.7 \mathrm{~Hz}, 3 \mathrm{H}), 0.90-0.85(\mathrm{~m}, 9 \mathrm{H}) ;{ }^{13} \mathrm{C} \mathrm{NMR}\left(\mathrm{CDCl}_{3}\right)$

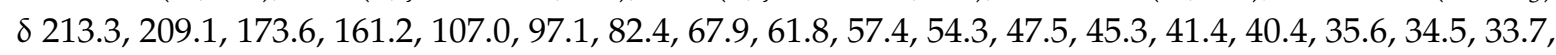
29.9, 29.6, 27.3, 25.8, 25.1, 23.7, 22.2, 20.5, 20.3, 18.8, 16.4, 12.6, 12.1; HRMS (ESI/Q-TOF): m/z 1119.6185 $[\mathrm{M}+\mathrm{Na}]^{+}$; for the compound $\mathrm{C}_{55} \mathrm{H}_{93} \mathrm{~N}_{4} \mathrm{O}_{16} \mathrm{P}$ requires 1119.6216.

4-(N-(3-ammoniopropyl)-4-((3-(diethoxyphosphoryl)propyl)(hydroxy)amino)-4-oxobutanamido)butan-1aminium 2,2,2-bis(trifluoroacetate) (24): Yellow oil (61 mg, 91\%); HRMS (ESI/Q-TOF): m/z 439.2687 $[\mathrm{M}+\mathrm{H}]^{+}$; for the compound $\mathrm{C}_{18} \mathrm{H}_{39} \mathrm{~N}_{4} \mathrm{O}_{6}$ P requires 439.2680 .

4,4'-((4-((3-(diethoxyphosphoryl)propyl)(hydroxy)amino)-4-oxobutanoyl)azanediyl)bis(butan-1-aminium) 2,2,2-bis(trifluoroacetate) (25): Yellow oil (65 mg, 95\%); HRMS (ESI/Q-TOF): m/z $453.2848[\mathrm{M}+\mathrm{H}]^{+}$; for the compound $\mathrm{C}_{19} \mathrm{H}_{41} \mathrm{~N}_{4} \mathrm{O}_{6} \mathrm{P}$ requires 453.2836.

\subsubsection{Synthesis of FSM-Amino and/or Amido Derivatives 26-33}

General procedure for the synthesis of Fosmidomycin conjugates with amines. To a solution of $42(1 \mathrm{mmol})$ in $\mathrm{CH}_{2} \mathrm{Cl}_{2}(1.4 \mathrm{~mL})$, the corresponding amines $(1 \mathrm{mmol})$, HBTU (1.1 mmol), and DIPEA $(1.5 \mathrm{mmol})$ were added. The reaction mixture was stirred at ambient temperature to complete the reaction (monitored by TLC) and then diluted with $\mathrm{CH}_{2} \mathrm{Cl}_{2}$, washed with $5 \%$ aqueous $\mathrm{NaHCO}_{3}$, pre-cooled $5 \%$ aqueous citric acid, water, and brine. The organic layer was dried over $\mathrm{Na}_{2} \mathrm{SO}_{4}$, filtered, and evaporated to dryness under reduced pressure. The residues thus obtained were subjected to FCC, affording the corresponding pure conjugates 60-67.

Tert-butyl 2-(4-((benzyloxy)(3-(diethoxyphosphoryl)propyl)amino)-4-oxobutanoyl) hydrazine-1-carboxylate (60): Reaction time: $5 \mathrm{~h}$; Yellow oil (320 mg, 62\%); $\mathrm{R}_{\mathrm{f}}\left(\mathrm{CHCl}_{3} / \mathrm{MeOH}\right.$ 97:3): $0.28 ;{ }^{1} \mathrm{H} \mathrm{NMR}\left(\mathrm{CDCl}_{3}\right) \delta 7.76$ (br s, $1 \mathrm{H}), 7.37(\mathrm{~s}, 5 \mathrm{H}), 4.85(\mathrm{~s}, 2 \mathrm{H}), 4.12-4.03(\mathrm{~m}, 4 \mathrm{H}), 3.74-3.68(\mathrm{~m}, 2 \mathrm{H}), 2.83-2.78(\mathrm{~m}, 2 \mathrm{H}), 2.55-2.50(\mathrm{~m}, 2 \mathrm{H})$, 1.96-1.88 (m, 2H), $1.69(\mathrm{br} \mathrm{s}, 2 \mathrm{H}), 1.48(\mathrm{~s}, 1 \mathrm{H}), 1.46(\mathrm{~s}, 8 \mathrm{H}), 1.30(\mathrm{t}, J=7.1 \mathrm{~Hz}, 6 \mathrm{H}) ;{ }^{13} \mathrm{C} \mathrm{NMR}\left(\mathrm{CDCl}_{3}\right) \delta$ 155.3, 129.3, 129.0, 128.8, 81.5, 76.6, 61.7, 61.6, 28.6, 28.2, 28.1, 27.7, 23.4, 22.5, 20.2, 16.4; ESI-MS (30eV): $m / z 554.32[\mathrm{M}+\mathrm{K}]^{+}, 538.45[\mathrm{M}+\mathrm{Na}]^{+}, 516.4[\mathrm{M}+\mathrm{H}]^{+}, 384.6\left[\mathrm{M}-\mathrm{C}_{5} \mathrm{H}_{11} \mathrm{~N}_{2} \mathrm{O}_{2}\right]^{+}$.

Diethyl(3-(4-((2-aminophenyl)amino)-N-(benzyloxy)-4-oxobutanamido) propyl) phosphonate (61): Reaction time: 4 h; Yellow oil (388 mg, 79\%); $\mathrm{R}_{\mathrm{f}}\left(\mathrm{CHCl}_{3} / \mathrm{MeOH} 98: 2\right): 0.15 ;{ }^{1} \mathrm{H} \mathrm{NMR}\left(\mathrm{CDCl}_{3}\right) \delta 7.77$ (br s, $\left.1 \mathrm{H}\right)$, $7.38(\mathrm{~s}, 5 \mathrm{H}), 7.21(\mathrm{dd}, J=8.2,1.3 \mathrm{~Hz}, 1 \mathrm{H}), 7.02(\mathrm{td}, J=7.7,1.4 \mathrm{~Hz}, 1 \mathrm{H}), 6.76-6.72(\mathrm{~m}, 2 \mathrm{H}), 4.86(\mathrm{~s}, 2 \mathrm{H})$, $4.11-4.01(\mathrm{~m}, 4 \mathrm{H}), 3.72(\mathrm{t}, J=6.2 \mathrm{~Hz}, 2 \mathrm{H}), 2.89(\mathrm{t}, J=6.0 \mathrm{~Hz}, 2 \mathrm{H}), 2.65(\mathrm{t}, J=6.6 \mathrm{~Hz}, 2 \mathrm{H}), 1.97-1.89(\mathrm{~m}$, $2 \mathrm{H}), 1.74-1.67(\mathrm{~m}, 2 \mathrm{H}), 1.28(\mathrm{t}, J=7.1 \mathrm{~Hz}, 6 \mathrm{H}) ;{ }^{13} \mathrm{C} \mathrm{NMR}\left(\mathrm{CDCl}_{3}\right) \delta 171.2,141.2,129.2,129.1,128.8$, 127.1, 125.8, 123.7, 118.8, 117.2, 76.5, 61.7, 61.6, 31.3, 28.5, 23.4, 22.3, 19.6, 16.5, 16.4; ESI-MS (30eV): $\mathrm{m} / \mathrm{z}$ $983.25[2 \mathrm{M}+\mathrm{H}]^{+}, 530.35[\mathrm{M}+\mathrm{K}]^{+}, 514.29[\mathrm{M}+\mathrm{Na}]^{+}, 492.37[\mathrm{M}+\mathrm{H}]^{+}, 384.3\left[\mathrm{M}-\mathrm{C}_{6} \mathrm{H}_{7} \mathrm{~N}_{2}\right]^{+}$. 
Diethyl(3-(N-(benzyloxy)-4-(dibenzylamino)-4-oxobutanamido)propyl)phosphonate (62): Reaction time: $5 \mathrm{~h}$; Pale yellow (441 mg, 76\%); Rf (AcOEt): 0.16; ${ }^{1} \mathrm{H}$ NMR $\left(\mathrm{CDCl}_{3}\right) \delta 7.43-7.40(\mathrm{~m}, 2 \mathrm{H}), 7.39-7.34(\mathrm{~m}, 5 \mathrm{H})$, 7.33-7.27 (m, 4H), 7.22-7.19 (m, 4H), $4.94(\mathrm{~s}, 2 \mathrm{H}), 4.61(\mathrm{~s}, 2 \mathrm{H}), 4.51(\mathrm{~s}, 2 \mathrm{H}), 4.12-4.02(\mathrm{~m}, 4 \mathrm{H}), 3.74$ $(\mathrm{t}, J=6.7 \mathrm{~Hz}, 2 \mathrm{H}), 2.91-2.86(\mathrm{~m}, 2 \mathrm{H}), 2.76(\mathrm{t}, J=6.4 \mathrm{~Hz}, 2 \mathrm{H}), 1.99-1.90(\mathrm{~m}, 2 \mathrm{H}), 1.79-1.70(\mathrm{~m}, 2 \mathrm{H})$, $1.28(\mathrm{t}, J=7.1 \mathrm{~Hz}, 6 \mathrm{H}) ;{ }^{13} \mathrm{C} \mathrm{NMR}\left(\mathrm{CDCl}_{3}\right) \delta 172.4,137.3,136.5,129.2,128.9,128.9,128.7,128.6,128.1$, 127.6, 127.3, 126.6, 76.5, 61.5, 49.9, 48.2, 27.8, 27.6, 23.5, 22.5, 20.3, 16.5, 16.4; ESI-MS (30eV): $\mathrm{m} / z 1183.64$ $[2 \mathrm{M}+\mathrm{Na}]^{+}, 619.25[\mathrm{M}+\mathrm{K}]^{+}, 603.22[\mathrm{M}+\mathrm{Na}]^{+}, 581.38[\mathrm{M}+\mathrm{H}]^{+}, 280.52\left[\mathrm{M}-\mathrm{C}_{14} \mathrm{H}_{23} \mathrm{NO}_{4} \mathrm{P}\right]^{+}$.

Tert-butyl(4-(4-(4-((benzyloxy)(3-(diethoxyphosphoryl)propyl)amino)-4-oxobutanamido)benzyl)phenyl)

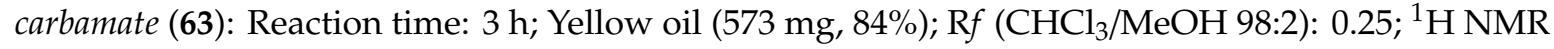
$\left(\mathrm{CDCl}_{3}\right) \delta 8.04(\mathrm{~s}, 1 \mathrm{H}), 7.39(\mathrm{t}, J=6.9 \mathrm{~Hz}, 2 \mathrm{H}), 7.36(\mathrm{~s}, 4 \mathrm{H}), 7.25(\mathrm{~s}, 2 \mathrm{H}), 7.24(\mathrm{~s}, 1 \mathrm{H}), 7.07(\mathrm{t}, J=8.7 \mathrm{~Hz}$, $4 \mathrm{H}), 6.42(\mathrm{~s}, 1 \mathrm{H}), 4.85(\mathrm{~s}, 2 \mathrm{H}), 4.12-3.97(\mathrm{~m}, 4 \mathrm{H}), 3.86(\mathrm{~s}, 2 \mathrm{H}), 3.72(\mathrm{~s}, 2 \mathrm{H}), 2.83(\mathrm{~s}, 2 \mathrm{H}), 2.64-2.59(\mathrm{~m}, 2 \mathrm{H})$, 1.96-1.88 (m, 2H), 1.75-1.67 (m, 2H), 1.49 (s, 9H), 1.27 (t, $J=7.1 \mathrm{~Hz}, 6 \mathrm{H})$; ESI-MS (30eV): m/z 1401.75 [2M $+\mathrm{K}]^{+}, 1385.75[2 \mathrm{M}+\mathrm{Na}]^{+}, 1363.84[2 \mathrm{M}+2 \mathrm{H}]^{+}, 720.36[\mathrm{M}+\mathrm{K}]^{+}, 704.49[\mathrm{M}+\mathrm{Na}]^{+}, 682.39[\mathrm{M}+\mathrm{H}]^{+}$.

Diethyl (3-(4-(benzylamino)-N-(benzyloxy)-4-oxobutanamido)propyl) phosphonate (64): Reaction time: 6 h; Yellow oil (363 mg 74\%); $\mathrm{Rf}\left(\mathrm{CHCl}_{3} / \mathrm{MeOH} 95: 5\right): 0.29 ;{ }^{1} \mathrm{H} \mathrm{NMR}\left(\mathrm{CDCl}_{3}\right) \delta 7.41-7.35(\mathrm{~m}, 5 \mathrm{H}), 7.34-7.29$ $(\mathrm{m}, 2 \mathrm{H}), 7.28-7.23(\mathrm{~m}, 3 \mathrm{H}), 6.27(\mathrm{~s}, 1 \mathrm{H}), 4.85(\mathrm{~s}, 2 \mathrm{H}), 4.43(\mathrm{~d}, J=5.7 \mathrm{~Hz}, 2 \mathrm{H}), 4.11-4.01(\mathrm{~m}, 4 \mathrm{H}), 3.70(\mathrm{t}$, $J=6.6 \mathrm{~Hz}, 2 \mathrm{H}), 2.81(\mathrm{t}, J=6.0 \mathrm{~Hz}, 2 \mathrm{H}), 2.52(\mathrm{t}, J=6.5 \mathrm{~Hz}, 2 \mathrm{H}), 1.96-1.87(\mathrm{~m}, 2 \mathrm{H}), 1.75-1.66(\mathrm{~m}, 2 \mathrm{H})$, $1.29(\mathrm{t}, J=7.1 \mathrm{~Hz}, 6 \mathrm{H}) ;{ }^{13} \mathrm{C} \mathrm{NMR}\left(\mathrm{CDCl}_{3}\right) \delta 173.8,172.0,138.4,134.3,129.2,129.0,128.7,128.6,127.7$, 127.4, 76.5, 61.6, 45.8, 43.6, 30.8, 28.1, 23.5, 22.5, 20.3, 16.5; ESI-MS (30eV): $m / z 529.34\left[\mathrm{M}+\mathrm{K}^{+}, 513.41\right.$ $[\mathrm{M}+\mathrm{Na}]^{+}, 491.49[\mathrm{M}+\mathrm{H}]^{+}, 384.36\left[\mathrm{M}-\mathrm{C}_{7} \mathrm{H}_{8} \mathrm{~N}\right]^{+}$.

Diethyl (3-(N-(benzyloxy)-4-oxo-4-(4-tritylpiperazin-1-yl)butanamido)propyl) phosphonate (66): Reaction time: $3 \mathrm{~h}$; Yellow oil (60 mg, 70\%); $\mathrm{R}_{\mathrm{f}}\left(\mathrm{CHCl}_{3} / \mathrm{MeOH} 99: 1\right): 0.18 ;{ }^{1} \mathrm{H} \mathrm{NMR}\left(\mathrm{CDCl}_{3}\right) \delta 7.47(\mathrm{br} \mathrm{s}, 5 \mathrm{H})$, 7.39-7.32 (m, 5H), 7.30-7.24 (m, 7H), 7.19-7.14 (m, 3H), $4.88(\mathrm{~s}, 2 \mathrm{H}), 4.10-4.02(\mathrm{~m}, 4 \mathrm{H}), 3.68(\mathrm{t}, J=6.5 \mathrm{~Hz}$, 2H), $3.62(\mathrm{~s}, 2 \mathrm{H}), 2.73(\mathrm{~s}, 2 \mathrm{H}), 2.54(\mathrm{t}, J=6.2 \mathrm{~Hz}, 2 \mathrm{H}), 2.17(\mathrm{~s}, 4 \mathrm{H}), 1.96-1.87(\mathrm{~m}, 2 \mathrm{H}), 1.75-1.65(\mathrm{~m}, 4 \mathrm{H})$, $1.28(\mathrm{t}, J=7.1 \mathrm{~Hz}, 6 \mathrm{H}) ;{ }^{13} \mathrm{C} \mathrm{NMR}\left(\mathrm{CDCl}_{3}\right) \delta 170.2,134.4,129.2,128.8,128.6,127.7,126.3,70.4,61.6,48.2$, $47.7,45.8,42.2,38.6,30.9,27.4,23.5,22.5,20.3,16.4$; ESI-MS $(30 \mathrm{eV}): \mathrm{m} / z 1445.58[2 \mathrm{M}+\mathrm{Na}]^{+}, 734.41$ $[\mathrm{M}+\mathrm{Na}]^{+}, 243.41[\mathrm{Trt}]^{+}$.

Diethyl (3-(N-(benzyloxy)-4-(4-methylpiperazin-1-yl)-4-oxobutanamido)propyl) phosphonate (67): Reaction time: $2 \mathrm{~h}$; Yellow oil (338 mg 70\%); $\mathrm{R}_{\mathrm{f}}\left(\mathrm{CHCl}_{3} / \mathrm{MeOH} 9: 1\right): 0.16 ;{ }^{1} \mathrm{H} \mathrm{NMR}\left(\mathrm{CDCl}_{3}\right) \delta 7.41-7.32(\mathrm{~m}, 5 \mathrm{H})$, $4.91(\mathrm{~s}, 2 \mathrm{H}), 4.11-4.01(\mathrm{~m}, 4 \mathrm{H}), 3.70(\mathrm{t}, J=6.8 \mathrm{~Hz}, 2 \mathrm{H}), 3.67-3.62(\mathrm{~m}, 2 \mathrm{H}), 3.56-3.52(\mathrm{~m}, 2 \mathrm{H}), 2.79(\mathrm{~s}, 2 \mathrm{H})$, $2.62(\mathrm{t}, J=6.5 \mathrm{~Hz}, 2 \mathrm{H}), 2.44(\mathrm{br} \mathrm{s}, 2 \mathrm{H}), 2.40(\mathrm{br} \mathrm{s}, 2 \mathrm{H}), 2.32(\mathrm{~s}, 3 \mathrm{H}), 1.96-1.88(\mathrm{~m}, 2 \mathrm{H}), 1.76-1.67(\mathrm{~m}$, $2 \mathrm{H}), 1.28(\mathrm{t}, J=7.1 \mathrm{~Hz}, 6 \mathrm{H}) ;{ }^{13} \mathrm{C} \mathrm{NMR}\left(\mathrm{CDCl}_{3}\right) \delta 137.1,128.8,128.4,128.0,76.3,61.5,59.2,59.1,29.7$, 24.0, 23.1, 20.3, 16.5; ESI-MS (30eV): $m / z 522.33[\mathrm{M}+\mathrm{K}]^{+}, 506.39[\mathrm{M}+\mathrm{Na}]^{+}, 484.41[\mathrm{M}+\mathrm{H}]^{+}, 384.35$ $\left[\mathrm{M}-\mathrm{C}_{5} \mathrm{H}_{11} \mathrm{~N}_{2}\right]^{+}$.

Trityl-deprotection of 4-(4-((benzyloxy)(3-(diethoxyphosphoryl) propyl)amino)-4-oxobutanoyl)piperazin1-ium2,2,2-trifluoroacetate (68): To an ice-cold solution of 66 (0.18 mmol) in $\mathrm{CH}_{2} \mathrm{Cl}_{2}(0.56 \mathrm{~mL})$, trifluroethanol (TFE) $(0.36 \mathrm{mmol})$ and TFA $(0.36 \mathrm{mmol})$ were added. The reaction mixture was stirred at ambient temperature for $1 \mathrm{~h}$. Volatile components were evaporated under vacuo, and the oily residue was triturated with $\mathrm{Et}_{2} \mathrm{O}$ and refrigerated overnight. The white precipitate was filtered under vacuum and dried to afford the trifluoroacetate salt 68 . White solid (74 mg, 70\%); $\mathrm{R}_{\mathrm{f}}\left(\mathrm{CHCl}_{3} / \mathrm{MeOH}\right.$ 9:1): 0.16; ${ }^{1} \mathrm{H}$ NMR (MeOD): $\delta 7.50-7.45$ (m, 2H), $7.44-7.38(\mathrm{~m}, 3 \mathrm{H}), 4.98(\mathrm{~s}, 2 \mathrm{H}), 4.13-4.02(\mathrm{~m}, 4 \mathrm{H})$, 3.86-3.75 (m, 6H), 3.21 (br s, 2H), 2.82 (br s, 2H), 2.72-2.67 (m, 2H), 1.95-1.87 (m, 2H), 1.84-1.78 (m, 2H), $1.31(\mathrm{t}, \mathrm{J}=7.1 \mathrm{~Hz}, 6 \mathrm{H})$.

Deprotection of intermediates 60-65, 67, and 68. A solution of 60-65, 67, and $68(0.1 \mathrm{mmol})$ in methanol $(3 \mathrm{~mL})$ was subjected to hydrogenolysis over $10 \% \mathrm{Pd} / \mathrm{C}$ at ambient temperature and pressure until completion of the reaction. Thus, the reaction mixture was filtered through Celite and the filter cake was washed several times with methanol. After evaporation of the solvent to dryness under 
reduced pressure, the residues were subjected to FCC, affording the corresponding pure deprotected molecules 26-33.

Tert-butyl 2-(4-((3-(diethoxyphosphoryl)propyl)(hydroxy)amino)-4-oxobutanoyl) hydrazine-1-carboxylate (26): Reaction time: $5 \mathrm{~h}$; Orange oil (38 mg 90\%); $\mathrm{R}_{\mathrm{f}}\left(\mathrm{CHCl}_{3} / \mathrm{MeOH} 95:\right): 0.19 ;{ }^{1} \mathrm{H}$ NMR $\left(\mathrm{CDCl}_{3}\right) \delta 9.58$ (s, $1 \mathrm{H}), 8.52(\mathrm{~s}, 1 \mathrm{H}), 7.05(\mathrm{~s}, 1 \mathrm{H}), 4.13-4.03(\mathrm{~m}, 4 \mathrm{H}), 3.70(\mathrm{t}, J=6.0 \mathrm{~Hz}, 2 \mathrm{H}), 2.86(\mathrm{t}, J=6.3 \mathrm{~Hz}, 2 \mathrm{H}), 2.58-2.52$ $(\mathrm{m}, 2 \mathrm{H}), 1.96-1.87(\mathrm{~m}, 2 \mathrm{H}), 1.78(\mathrm{~m}, 2 \mathrm{H}), 1.47(\mathrm{~s}, 1 \mathrm{H}), 1.45(\mathrm{~s}, 8 \mathrm{H}), 1.31(\mathrm{t}, J=7.0 \mathrm{~Hz}, 6 \mathrm{H}) ;{ }^{13} \mathrm{C} \mathrm{NMR}$ $\left(\mathrm{CDCl}_{3}\right) \delta 173.3,155.6,81.5,62.1,47.9,29.3,28.2,27.7,22.8,21.8,19.4,16.4 ;$ HRMS (ESI/Q-TOF): $\mathrm{m} / \mathrm{z}$ $426.2000[\mathrm{M}+\mathrm{H}]^{+}$; for the compound $\mathrm{C}_{16} \mathrm{H}_{32} \mathrm{~N}_{3} \mathrm{O}_{8} \mathrm{P}$ requires 426.2005.

Diethyl(3-(4-((2-aminophenyl)amino)-N-hydroxy-4-oxobutanamido) propyl) phosphonate (27): Reaction time: $3 \mathrm{~h}$; Yellow oil (54 mg, 89\%); $\mathrm{R}_{\mathrm{f}}\left(\mathrm{CHCl}_{3} / \mathrm{MeOH} 95: 5\right): 0.11 ;{ }^{1} \mathrm{H} \mathrm{NMR}\left(\mathrm{CDCl}_{3}\right) \delta 9.76(\mathrm{br} \mathrm{s}, 1 \mathrm{H}), 8.20$ (s, $1 \mathrm{H}), 7.20(\mathrm{~d}, J=7.9 \mathrm{~Hz}, 1 \mathrm{H}), 7.02-6.99(\mathrm{~m}, 1 \mathrm{H}), 6.74-6.71(\mathrm{~m}, 1 \mathrm{H}), 4.04-3.99(\mathrm{~m}, 4 \mathrm{H}), 3.72(\mathrm{t}, J=6.1 \mathrm{~Hz}$, 2H), 2.96-2.92 (m, 2H), 2.70-2.66 (m, 2H), 1.97-1.89 (m, 2H), $1.78(\mathrm{dt}, J=18.5,6.9 \mathrm{~Hz}, 2 \mathrm{H}), 1.26(\mathrm{t}$, $J=7.1 \mathrm{~Hz}, 6 \mathrm{H}) ;{ }^{13} \mathrm{C} \mathrm{NMR}\left(\mathrm{CDCl}_{3}\right) \delta 173.9,172.0,141.0,127.0,125.7,123.8,118.8,117.1,62.3,62.2$, 47.9, 31.9, 28.6, 22.8, 21.8, 19.2, 16.3; HRMS (ESI/Q-TOF): $m / z 424.1615[\mathrm{M}+\mathrm{Na}]^{+}$; for the compound $\mathrm{C}_{17} \mathrm{H}_{28} \mathrm{~N}_{3} \mathrm{O}_{6}$ P requires 424.1608 .

Diethyl (3-(4-(dibenzylamino)-N-hydroxy-4-oxobutanamido) propyl)phosphonate (28): Reaction time: $4 \mathrm{~h}$; Yellow oil (39 mg, 80\%); $\mathrm{R}_{\mathrm{f}}\left(\mathrm{CHCl}_{3} / \mathrm{MeOH} 98: 2\right): 0.21 ;{ }^{1} \mathrm{H} \mathrm{NMR}\left(\mathrm{CDCl}_{3}\right) \delta 9.86(\mathrm{~s}, 1 \mathrm{H}), 7.39-7.34(\mathrm{~m}$, 2H), 7.33-7.27 (m, 4H), 7.21-7.13 (m, 4H), $4.59(\mathrm{~s}, 2 \mathrm{H}), 4.49(\mathrm{~s}, 2 \mathrm{H}), 4.14-4.02(\mathrm{~m}, 4 \mathrm{H}), 3.75(\mathrm{t}, J=6.0 \mathrm{~Hz}$, $2 \mathrm{H}), 2.91-2.81(\mathrm{~m}, 4 \mathrm{H}), 2.01-1.92(\mathrm{~m}, 2 \mathrm{H}), 1.81(\mathrm{dt}, J=18.2,7.1 \mathrm{~Hz}, 2 \mathrm{H}), 1.28(\mathrm{t}, J=7.0 \mathrm{~Hz}, 6 \mathrm{H}) ;{ }^{13} \mathrm{C}$ NMR $\left(\mathrm{CDCl}_{3}\right) \delta 173.3,173.2,136.9,136.0,129.0,128.6,128.1,127.7,127.4,126.5,61.9,50.0,48.5,47.6$, 47.5, 29.2, 27.3, 22.8, 21.9, 19.3, 16.4; HRMS (ESI/Q-TOF): $\mathrm{m} / z 491.2311[\mathrm{M}+\mathrm{H}]^{+}$; for the compound $\mathrm{C}_{25} \mathrm{H}_{35} \mathrm{~N}_{2} \mathrm{O}_{6}$ P requires 491.2305.

Tert-butyl(4-(4-(4-((3-(diethoxyphosphoryl)propyl)(hydroxy)amino)-4-oxobutanamido)benzyl)phenyl) carbamate (29): Reaction time: $3 \mathrm{~h}$; light yellow oil (53 mg, 90\%); $\mathrm{R}_{\mathrm{f}}\left(\mathrm{CHCl}_{3} / \mathrm{MeOH} 97: 3\right): 0.09 ;{ }^{1} \mathrm{H} \mathrm{NMR}\left(\mathrm{CDCl}_{3}\right)$ $\delta 9.78(\mathrm{br} \mathrm{s}, 1 \mathrm{H}), 8.70(\mathrm{~s}, 1 \mathrm{H}), 7.40(\mathrm{~d}, J=8.3 \mathrm{~Hz}, 2 \mathrm{H}), 7.24(\mathrm{~d}, J=7.8 \mathrm{~Hz}, 2 \mathrm{H}), 7.07-7.03(\mathrm{~m}, 4 \mathrm{H}), 6.48(\mathrm{~s}$, $1 \mathrm{H}), 4.00$ (quint, $J=14.4,7.0 \mathrm{~Hz}, 4 \mathrm{H}), 3.85(\mathrm{~s}, 2 \mathrm{H}), 3.74(\mathrm{t}, J=6.0 \mathrm{~Hz}, 2 \mathrm{H}), 2.94-2.88(\mathrm{~m}, 2 \mathrm{H}), 2.70-2.62$ $(\mathrm{m}, 2 \mathrm{H}), 1.99-1.90(\mathrm{~m}, 3 \mathrm{H}), 1.82-1.74(\mathrm{~m}, 2 \mathrm{H}), 1.50(\mathrm{~s}, 9 \mathrm{H}), 1.23(\mathrm{t}, J=7.1 \mathrm{~Hz}, 6 \mathrm{H}) ;{ }^{13} \mathrm{C} \mathrm{NMR}\left(\mathrm{CDCl}_{3}\right) \delta$ 173.9, 171.3, 152.9, 136.9, 136.4, 135.9, 129.3, 129.2, 129.0, 128.2, 125.3, 119.9, 118.8, 62.3, 47.9, 40.6, 32.6, 28.4, 22.7, 21.8, 19.1, 16.3; HRMS (ESI/Q-TOF): $m / z 592.2787[\mathrm{M}+\mathrm{H}]^{+}$; for the compound $\mathrm{C}_{29} \mathrm{H}_{42} \mathrm{~N}_{3} \mathrm{O}_{8} \mathrm{P}$ requires 592.2782 .

Diethyl (3-(4-(benzylamino)-N-hydroxy-4-oxobutanamido)propyl) phosphonate (30): Reaction time: $3 \mathrm{~h}$; Reddish oil (36 mg, 90\%); $\mathrm{R}_{\mathrm{f}}\left(\mathrm{CHCl}_{3} / \mathrm{MeOH} 95: 5\right): 0.09 ;{ }^{1} \mathrm{H} \mathrm{NMR}\left(\mathrm{CDCl}_{3}\right) \delta 9.83$ (br s, $\left.1 \mathrm{H}\right), 7.32-7.27$ $(\mathrm{m}, 2 \mathrm{H}), 7.25-7.21(\mathrm{~m}, 3 \mathrm{H}), 6.78(\mathrm{~s}, 1 \mathrm{H}), 4.38(\mathrm{~s}, 2 \mathrm{H}), 4.09-4.00(\mathrm{~m}, 4 \mathrm{H}), 3.71-3.65(\mathrm{~m}, 2 \mathrm{H}), 2.84(\mathrm{~s}, 2 \mathrm{H})$, $2.56(\mathrm{~s}, 2 \mathrm{H}), 1.97-1.87(\mathrm{~m}, 2 \mathrm{H}), 1.81-1.71(\mathrm{~m}, 2 \mathrm{H}), 1.29(\mathrm{t}, J=7.0 \mathrm{~Hz}, 6 \mathrm{H}) ;{ }^{13} \mathrm{C} \mathrm{NMR}\left(\mathrm{CDCl}_{3}\right) \delta 173.5$, 172.9, 138.3, 128.6, 127.6, 127.3, 62.1, 47.8, 47.7, 43.6, 31.4, 27.9, 22.8, 21.9, 19.4, 16.4; HRMS (ESI/Q-TOF): $\mathrm{m} / \mathrm{z} 423.1657[\mathrm{M}+\mathrm{Na}]^{+}$; for the compound $\mathrm{C}_{18} \mathrm{H}_{29} \mathrm{~N}_{2} \mathrm{O}_{6} \mathrm{P}$ requires 423.1655.

Diethyl(3-(4-(benzhydrylamino)-N-hydroxy-4-oxobutanamido)propyl)phosphonate (31): Reaction time: $3 \mathrm{~h}$; Reddish oil (40 mg, 85\%); $\mathrm{R}_{\mathrm{f}}$ (PhMe/AcOEt 4:6): 0.1; ${ }^{1} \mathrm{H}$ NMR $\left(\mathrm{CDCl}_{3}\right) \delta$ 7.40-7.09 (m, 10), 6.25-6.11 (m, 1H), 4.17-3.95 (m, 4H), 3.76-3.61 (m, 2H), $2.84(\mathrm{~s}, 2 \mathrm{H}), 2.59(\mathrm{~s}, 2 \mathrm{H}), 2.07-1.85(\mathrm{~m}, 2 \mathrm{H}), 1.84-1.65$ $(\mathrm{m}, 2 \mathrm{H}), 1.34-1.21(\mathrm{~m}, 6 \mathrm{H}) ;{ }^{13} \mathrm{C} \mathrm{NMR}\left(\mathrm{CDCl}_{3}\right) \delta 173.7,172.2,141.7,128.6,127.4,127.3,62.1,56.0,50.8$, 47.3, 31.5, 28.8, 28.0, 21.5, 19.3, 16.4; HRMS (ESI/Q-TOF): $m / z 499.1979[\mathrm{M}+\mathrm{Na}]^{+}$; for the compound $\mathrm{C}_{24} \mathrm{H}_{33} \mathrm{~N}_{2} \mathrm{O}_{6}$ P requires 499.1968 .

Diethyl (3-(N-hydroxy-4-(4-methylpiperazin-1-yl)-4-oxobutanamido) propyl) phosphonate (32): Reaction time: $2 \mathrm{~h}$; Orange oil (35 mg, 90\%); $\mathrm{R}_{\mathrm{f}}\left(\mathrm{CHCl}_{3} / \mathrm{MeOH} 8: 2\right): 0.29 ;{ }^{1} \mathrm{H} \mathrm{NMR}\left(\mathrm{CDCl}_{3}\right) \delta 4.16-4.01(\mathrm{~m}, 7 \mathrm{H}), 3.70$ $(\mathrm{t}, J=6.9 \mathrm{~Hz}, 1 \mathrm{H}), 3.62(\mathrm{br} \mathrm{s}, 2 \mathrm{H}), 3.52(\mathrm{t}, J=5.2 \mathrm{~Hz}, 2 \mathrm{H}), 2.79(\mathrm{t}, J=6.8 \mathrm{~Hz}, 1 \mathrm{H}), 2.70(\mathrm{t}, J=7.0 \mathrm{~Hz}$, $1 \mathrm{H}), 2.65$ (quint, $J=10.8,4.5 \mathrm{~Hz}, 1 \mathrm{H}), 2.45$ (br s, $1 \mathrm{H}), 2.40(\mathrm{br} \mathrm{s}, 1 \mathrm{H}), 2.32(\mathrm{~s}, 3 \mathrm{H}), 1.97-1.90(\mathrm{~m}, 2 \mathrm{H})$, $1.80-1.73(\mathrm{~m}, 2 \mathrm{H}), 1.31(\mathrm{t}, J=7.0 \mathrm{~Hz}, 6 \mathrm{H}) ;{ }^{13} \mathrm{C} \mathrm{NMR}\left(\mathrm{CDCl}_{3}\right) \delta 173.7,173.2,62.2,51.7,47.8,29.0,28.7,27.5$, 
22.5, 21.6, 19.0, 16.4; HRMS (ESI/Q-TOF): $\mathrm{m} / \mathrm{z} 416.1848[\mathrm{M}+\mathrm{Na}]^{+}$; for the compound $\mathrm{C}_{16} \mathrm{H}_{32} \mathrm{~N}_{3} \mathrm{O}_{6} \mathrm{P}$ requires 416.1921.

4-(4-((3-(Diethoxyphosphoryl)propyl)(hydroxy)amino)-4-oxobutanoyl)piperazin-1-ium 2,2,2-trifluoroacetate (33): Reaction time: $4 \mathrm{~h}$; Yellow oil $(30 \mathrm{mg}, 60 \%) ; \mathrm{R}_{\mathrm{f}}\left(\mathrm{CHCl}_{3} / \mathrm{MeOH} 8: 2\right): 0.22 ;{ }^{1} \mathrm{H} \mathrm{NMR}\left(\mathrm{CDCl}_{3}\right) \delta$ $9.84(\mathrm{br} \mathrm{s}, 1 \mathrm{H}), 4.13-4.02(\mathrm{~m}, 4 \mathrm{H}), 3.82(\mathrm{br} \mathrm{s}, 2 \mathrm{H}), 3.74-3.66(\mathrm{~m}, 2 \mathrm{H}), 3.24-3.10(\mathrm{~m}, 2 \mathrm{H}), 2.84(\mathrm{~s}, 2 \mathrm{H})$, 2.68-2.62 (m, 2H), $2.55(\mathrm{~s}, 1 \mathrm{H}), 1.98-1.88(\mathrm{~m}, 2 \mathrm{H}), 1.78(\mathrm{dt}, J=18.0,6.9 \mathrm{~Hz}, 2 \mathrm{H}), 1.34-1.29(\mathrm{~m}, 6 \mathrm{H})$; ${ }^{13} \mathrm{C} \mathrm{NMR}\left(\mathrm{CDCl}_{3}\right) \delta 173.2,171.3,62.1,53.7,48.5,43.4,29.7,27.4,22.7,21.7,19.4,16.4$; HRMS (ESI/Q-TOF): $\mathrm{m} / \mathrm{z} 380.1948[\mathrm{M}+\mathrm{H}]^{+}$; for the compound $\mathrm{C}_{15} \mathrm{H}_{30} \mathrm{~N}_{3} \mathrm{O}_{6} \mathrm{P}$ requires 380.1945 .

Diethyl (3-((2-aminophenyl)amino)propyl)phosphonate (34): To a solution of bromide 37 (90 $\mathrm{mg}$, $0.35 \mathrm{mmol})$ and ortho-benzenediamine $(35 \mathrm{mg}, 0.35 \mathrm{mmol})$ in dimethylformamide (DMF) $(0.46 \mathrm{~mL})$, 1,8-diazabicyclo[5.4.0]undec-7-ene (DBU) $(106 \mathrm{mg}, 0.7 \mathrm{mmol})$ was added and the reaction mixture was subjected to ultrasonic radiation at $40{ }^{\circ} \mathrm{C}$ for $1 \mathrm{~h}$. Upon completion of the reaction, the mixture was diluted $\mathrm{CH}_{2} \mathrm{Cl}_{2}$, and washed three times with water and once with brine. The organic layer was dried over $\mathrm{Na}_{2} \mathrm{SO}_{4}$ and evaporated to dryness under pressure. The residue was purified by FCC, affording compound 34; orange oil (33 mg, 33\%); $\mathrm{R}_{\mathrm{f}}\left(\mathrm{CHCl}_{3} / \mathrm{MeOH} 97: 3\right): 0.3 ;{ }^{1} \mathrm{H} \mathrm{NMR}\left(\mathrm{CDCl}_{3}\right): \delta 6.79(\mathrm{dt}$, $J=7.5,1.6 \mathrm{~Hz}, 1 \mathrm{H}), 6.70(\mathrm{dd}, J=7.7,1.9 \mathrm{~Hz}, 1 \mathrm{H}), 6.68-6.60(\mathrm{~m}, 2 \mathrm{H}), 4.15-4.04(\mathrm{~m}, 4 \mathrm{H}), 3.20(\mathrm{t}, J=6.6 \mathrm{~Hz}$, 2H), 2.01-1.92 (m, 2H), 1.921-1.84 (m, 2H), $1.31(\mathrm{t}, J=7.0 \mathrm{~Hz}, 6 \mathrm{H}) ;{ }^{13} \mathrm{C} \mathrm{NMR}\left(\mathrm{CDCl}_{3}\right) \delta 137.4,134.3$, 120.5, 118.6, 116.4, 111.6, 61.6, 44.4, 44.3, 23.9, 23.0, 22.5, 22.5, 16.5; HRMS (ESI/Q-TOF): $\mathrm{m} / z$ 287.1525 $[\mathrm{M}+\mathrm{H}]^{+}$; for the compound $\mathrm{C}_{13} \mathrm{H}_{23} \mathrm{~N}_{2} \mathrm{O}_{3}$ P requires 287.1519 .

(3-((2-Aminophenyl)amino)propyl)phosphonic acid (35): To an ice-cold solution of $\mathbf{3 4}$ (30 mg, $0.1 \mathrm{mmol})$ in $\mathrm{CH}_{2} \mathrm{Cl}_{2}(0.33 \mathrm{~mL})$, bromotrimethylsilane (TMSBr) $(0.16 \mathrm{~mL}, 1.2 \mathrm{mmol})$ was added dropwise and the reaction mixture was stirred at room temperature for $8 \mathrm{~h}$. Then, it was concentrated under vacuum and treated with a solution of $\mathrm{NaOH}(0.41 \mathrm{mg}, 0.1 \mathrm{mmol})$ in $\mathrm{MeOH} / \mathrm{H}_{2} \mathrm{O}$ 9:1 $(1 \mathrm{~mL})$ at room temperature for $40 \mathrm{~min}$ The monosodium salt 35 was received after evaporation of the solvents to dryness under reduced pressure as an orange oil $(19 \mathrm{mg}, 75 \%) ;{ }^{1} \mathrm{H}$ NMR $\left(\mathrm{H}_{2} \mathrm{D}\right): \delta 7.18-7.09(\mathrm{~m}, 3 \mathrm{H})$, 7.08-7.04 (m, 1H), $3.32(\mathrm{t}, J=7.4 \mathrm{~Hz}, 2 \mathrm{H}), 1.92-1.84(\mathrm{~m}, 2 \mathrm{H}), 1.82-1.75(\mathrm{~m}, 2 \mathrm{H}) ;{ }^{13} \mathrm{C} \mathrm{NMR}\left(\mathrm{H}_{2} \mathrm{D}\right) \delta 131.8$, 126.7, 125.4, 122.9, 119.8, 47.7, 24.3, 23.4, 20.5; ESI-MS (30eV): $\mathrm{m} / \mathrm{z} 499.34[2 \mathrm{M}+\mathrm{K}]^{+}, 483.42[2 \mathrm{M}+\mathrm{Na}]^{+}$, $461.45[2 \mathrm{M}+\mathrm{H}]^{+}, 269.48[\mathrm{M}+\mathrm{K}]^{+}, 253.5[\mathrm{M}+\mathrm{Na}]^{+}, 231.53[\mathrm{M}+\mathrm{H}]^{+}$.

\subsection{Biological Evaluation}

\subsubsection{Biological Assays}

Cytotoxicity evaluation was performed upon human primary fibroblasts (cell line AB943) [35]. Assays were realized in 96-well plates in DMEM + Glutamax without phenol red medium (Gibco) containing $25 \mathrm{mM}$ HEPES, $\mathrm{pH} 7.3,10 \%$ fetal calf serum under a $5 \% \mathrm{CO}_{2}$ atmosphere, at $37{ }^{\circ} \mathrm{C}$. After trypsin treatment, AB943 cells were seeded at 2000 cells per well in $100 \mu \mathrm{L}$. After $24 \mathrm{~h}$ of incubation, drugs diluted in culture medium were added (100 $\mu \mathrm{L}$ per well). Drug stock solutions were prepared in dimethyl sulfoxide (DMSO). The final DMSO concentration in the cultures remained below $1 \%$. Control cultures were constituted of cultures treated with DMSO instead of drug. The cytotoxicity assay was based on the conversion of a redo-sensitive dye (resazurin) to a fluorescent product by viable cells. After $72 \mathrm{~h}$ of incubation, resazurin solution was added in each well at a final concentration of $45 \mu \mathrm{M}$. Fluorescence was measured at $530 \mathrm{~nm}$ excitation and $590 \mathrm{~nm}$ emission wavelengths after $4 \mathrm{~h}$ of incubation. The percentage of inhibition of cell growth was calculated by comparing the fluorescence of cells maintained in the presence of drug to that in the absence of drug. The concentration causing $50 \%$ growth inhibition $\left(\mathrm{IC}_{50}\right)$ was obtained from the drug concentration-response curve and the results were expressed as the mean values \pm standard deviations determined from several independent experiments. 


\subsubsection{In Vitro Growth Inhibition of P. falciparum}

The chloroquine-resistant FcB1/Colombia strain of Plasmodium falciparum was maintained in vitro on human erythrocytes in RPMI 1640 medium supplemented by $8 \%(v / v)$ heat-inactivated human serum, at $37^{\circ} \mathrm{C}$, under an atmosphere of $3 \% \mathrm{CO}_{2}, 6 \% \mathrm{O}_{2}$, and $91 \% \mathrm{~N}_{2}$ [45]. In vitro drug susceptibility assays were measured by $\left[{ }^{3} \mathrm{H}\right]$-hypoxanthine incorporation. Drug stock solutions were prepared in DMSO. Compounds were serially diluted two-fold with $100 \mu \mathrm{L}$ of culture medium in 96-well plates. Asynchronous parasite cultures $(100 \mu \mathrm{L}, 1 \%$ parasitaemia and $1 \%$ final hematocrite) were then added to each well and incubated for $24 \mathrm{~h}$ at $37{ }^{\circ} \mathrm{C}$ prior to the addition of $0.5 \mu \mathrm{Ci}$ of $\left[{ }^{3} \mathrm{H}\right]$-hypoxanthine (GE Healthcare, France, 1 to $5 \mathrm{Ci} \cdot \mathrm{mmol} / \mathrm{mL}$ ) per well [42]. After a further incubation of $24 \mathrm{~h}$, plates were frozen and thawed. Cell lysates were then collected onto fiberglass filters and counted in a liquid scintillation spectrometer. The growth inhibition for each drug concentration was determined by comparison of the radioactivity incorporated in the treated culture with that in the control culture maintained on the same plate. The $\mathrm{IC}_{50}$ value was obtained from the drug concentration-response curve and the results were expressed as the mean values \pm standard deviations determined from several independent experiments. Chloroquine and artemisinin were used as antimalarial drug controls.

Supplementary Materials: The following are available online, Figure S1: ${ }^{1} \mathrm{H}-\mathrm{NMR}$ spectrum of compound 42, Figure S2: ${ }^{13} \mathrm{C}-\mathrm{NMR}$ spectrum of compound 42, Figure S3: ${ }^{31} \mathrm{P}-\mathrm{NMR}$ spectrum of compound 42, Figure S4: ${ }^{1} \mathrm{H}-\mathrm{NMR}$ spectrum of compound 43, Figure S5: ${ }^{13} \mathrm{C}-\mathrm{NMR}$ spectrum of compound 43, Figure S6: ${ }^{1} \mathrm{H}-\mathrm{NMR}$ spectrum of compound 18, Figure S7: ${ }^{13} \mathrm{C}-\mathrm{NMR}$ spectrum of compound 18, Figure S8: ${ }^{1} \mathrm{H}-\mathrm{NMR}$ spectrum of compound 47, Figure S9: ${ }^{13} \mathrm{C}-\mathrm{NMR}$ spectrum of compound 47, Figure S10: ${ }^{1} \mathrm{H}-\mathrm{NMR}$ spectrum of compound 19, Figure S11: ${ }^{13} \mathrm{C}-\mathrm{NMR}$ spectrum of compound 19, Figure S12: ${ }^{1} \mathrm{H}-\mathrm{NMR}$ spectrum of compound 20, Figure S13: ${ }^{13} \mathrm{C}-\mathrm{NMR}$ spectrum of compound 20, Figure S14: ${ }^{1} \mathrm{H}-\mathrm{NMR}$ spectrum of compound 21, Figure S15: ${ }^{13} \mathrm{C}-\mathrm{NMR}$ spectrum of compound 21, Figure S16: ${ }^{1} \mathrm{H}-\mathrm{NMR}$ spectrum of compound 54, Figure S17: ${ }^{13} \mathrm{C}$-NMR spectrum of compound 54, Figure S18: ${ }^{1} \mathrm{H}-\mathrm{NMR}$ spectrum of compound 55, Figure S19: ${ }^{13} \mathrm{C}-\mathrm{NMR}$ spectrum of compound 55, Figure S20: ${ }^{1} \mathrm{H}-\mathrm{NMR}$ spectrum of compound 56, Figure S21: ${ }^{13} \mathrm{C}$-NMR spectrum of compound 56, Figure S22: ${ }^{1} \mathrm{H}-\mathrm{NMR}$ spectrum of compound 57, Figure S23: ${ }^{13} \mathrm{C}-\mathrm{NMR}$ spectrum of compound 57, Figure S24: ${ }^{1} \mathrm{H}-\mathrm{NMR}$ spectrum of compound 22, Figure S25: ${ }^{13} \mathrm{C}-\mathrm{NMR}$ spectrum of compound 22, Figure S26: ${ }^{1} \mathrm{H}-\mathrm{NMR}$ spectrum of compound 23, Figure S27: ${ }^{13} \mathrm{C}-\mathrm{NMR}$ spectrum of compound 23, Figure S28: ${ }^{1} \mathrm{H}-\mathrm{NMR}$ spectrum of compound 60, Figure S29: ${ }^{13} \mathrm{C}-\mathrm{NMR}$ spectrum of compound 60, Figure S30: ${ }^{1} \mathrm{H}-\mathrm{NMR}$ spectrum of compound 61, Figure S31: ${ }^{13} \mathrm{C}-\mathrm{NMR}$ spectrum of compound 61, Figure S32: ${ }^{1} \mathrm{H}-\mathrm{NMR}$ spectrum of compound 62, Figure S33: ${ }^{13} \mathrm{C}-\mathrm{NMR}$ spectrum of compound 62, Figure S34: ${ }^{1} \mathrm{H}-\mathrm{NMR}$ spectrum of compound 63, Figure S35: ${ }^{1} \mathrm{H}-\mathrm{NMR}$ spectrum of compound 64, Figure S36: ${ }^{13} \mathrm{C}-\mathrm{NMR}$ spectrum of compound 64, Figure S37: ${ }^{1} \mathrm{H}-\mathrm{NMR}$ spectrum of compound 66, Figure S38: ${ }^{13} \mathrm{C}-\mathrm{NMR}$ spectrum of compound 66, Figure S39: ${ }^{1} \mathrm{H}-\mathrm{NMR}$ spectrum of compound 67, Figure S40: ${ }^{13} \mathrm{C}-\mathrm{NMR}$ spectrum of compound 67, Figure S41: ${ }^{1} \mathrm{H}-\mathrm{NMR}$ spectrum of compound 68, Figure S42: ${ }^{1} \mathrm{H}-\mathrm{NMR}$ spectrum of compound 26, Figure S43: ${ }^{13} \mathrm{C}-\mathrm{NMR}$ spectrum of compound 26, Figure S44: ${ }^{1} \mathrm{H}-\mathrm{NMR}$ spectrum of compound 27, Figure S45: ${ }^{13} \mathrm{C}-\mathrm{NMR}$ spectrum of compound 27, Figure S46: ${ }^{1} \mathrm{H}-\mathrm{NMR}$ spectrum of compound 28, Figure S47: ${ }^{13} \mathrm{C}-\mathrm{NMR}$ spectrum of compound 28, Figure S48: ${ }^{1} \mathrm{H}-\mathrm{NMR}$ spectrum of compound 29, Figure S49: ${ }^{13} \mathrm{C}-\mathrm{NMR}$ spectrum of compound 29, Figure S50: ${ }^{1} \mathrm{H}-\mathrm{NMR}$ spectrum of compound 30, Figure S51: ${ }^{13} \mathrm{C}-\mathrm{NMR}$ spectrum of compound 30, Figure S52: ${ }^{1} \mathrm{H}-\mathrm{NMR}$ spectrum of compound 31, Figure S53: ${ }^{13} \mathrm{C}-\mathrm{NMR}$ spectrum of compound 31, Figure S54: ${ }^{13} \mathrm{C}-\mathrm{NMR}$ spectrum of compound 32, Figure S55: ${ }^{13} \mathrm{C}$-NMR spectrum of compound 32, Figure S56: ${ }^{1} \mathrm{H}-\mathrm{NMR}$ spectrum of compound 33, Figure S57: ${ }^{1} \mathrm{H}-\mathrm{NMR}$ spectrum of compound 33, Figure S58: ${ }^{1} \mathrm{H}-\mathrm{NMR}$ spectrum of compound 34, Figure S59: ${ }^{13} \mathrm{C}-\mathrm{NMR}$ spectrum of compound 34, Figure S60: ${ }^{1} \mathrm{H}-\mathrm{NMR}$ spectrum of compound 35, Figure S61: ${ }^{13} \mathrm{C}-\mathrm{NMR}$ spectrum of compound 35.

Author Contributions: Conceptualization, C.M.A.; methodology, C.M.A., M.B., P.G. and E.M.; NMR and MS analysis, C.M.A., D.P. and A.I.A.; investigation, D.P., A.I.A., P.G., and E.M.; and C.M. for several purifications; writing-original draft preparation, C.M.A. and M.B.; writing-review and editing, C.M.A., M.B., P.G., E.M., A.I.A., D.P.; supervision, C.M.A.; project administration, C.M.A. All authors have read and agreed to the published version of the manuscript.

Funding: This research received no external funding.

Acknowledgments: We would like to thank the CNRS, the University of Patras and the University Paul Sabatier for financial support. The authors would also like to acknowledge the Instrumental Analysis Laboratory (EEA, School of Natural Sciences, University of Patras) for carrying out the NMR analyses and the ICT Mass Spectrometry facility (http://ict.ups-tlse.fr/?HPLC-102) for the recording of HRMS spectra.

Conflicts of Interest: The authors declare no conflict of interest. 


\section{References}

1. WHO World Malaria Report. 2019. Available online: https://www.who.int/malaria/publications/worldmalaria-report-2019/en/ (accessed on 4 December 2019).

2. Dondorp, A.M.; Yeung, S.; White, L.; Nguon, C.; Day, N.P.J.; Socheat, D.; von Seidlein, L. Artemisinin resistance: Current status and scenarios for containment. Nat. Rev. Microbiol. 2010, 8, 272-280. [CrossRef] [PubMed]

3. Rohmer, M.; Knani, M.; Simonin, P.; Sutter, B.; Sahm, H. Isoprenoid biosynthesis in bacteria: A novel pathway for the early steps leading to isopentenyl diphosphate. Biochem. J. 1993, 295, 517-524. [CrossRef] [PubMed]

4. Rodriguez-Concepcion, M. The MEP Pathway: A New Target for the Development of Herbicides, Antibiotics and Antimalarial Drugs. Curr. Pharm. Des. 2004, 10, 2391-2400. [CrossRef] [PubMed]

5. Rohdich, F.; Bacher, A.; Eisenreich, W. Isoprenoid biosynthetic pathways as anti-infective drug targets. Biochem. Soc. Trans. 2005, 33, 785-791. [CrossRef] [PubMed]

6. McFadden, G.I. The apicoplast. Protoplasma 2011, 248, 641-650. [CrossRef] [PubMed]

7. Ralph, S.A.; D'Ombrain, M.C.; McFadden, G.I. The apicoplast as an antimalarial drug target. Drug Resist. Updates 2001, 4, 145-151. [CrossRef] [PubMed]

8. Sato, S. The apicomplexan plastid and its evolution. Cell. Mol. Life Sci. 2011, 68, 1285-1296. [CrossRef]

9. Jomaa, H.; Wiesner, J.; Sanderbrand, S.; Altincicek, B.; Weidemeyer, C.; Hintz, M.; Turbachova, I.; Eberl, M.; Zeidler, J.; Lichtenthaler, H.K.; et al. Inhibitors of the nonmevalonate pathway of isoprenoid biosynthesis as antimalarial drugs. Science 1999, 285, 1573-1576. [CrossRef]

10. Okuhara, M.; Kuroda, Y.; Goto, T.; Okamoto, M.; Terano, H.; Kohsaka, M.; Aoki, H.; Imanaka, H. Studies on new phosphonic acid antibiotics. III. Isolation and characterization of FR-31564, FR-32863 and FR-33289. J. Antibiot. (Tokyo) 1980, 33, 24-28. [CrossRef]

11. Kuroda, Y.; Okuhara, M.; Goto, T.; Okamoto, M.; Terano, H.; Kohsaka, M.; Aoki, H.; Imanaka, H. Studies on new phosphonic acid antibiotics. IV. Structure determination of FR-33289, FR-31564 and FR-32863. J. Antibiot. (Tokyo) 1980, 33, 29-35. [CrossRef]

12. Hirsch, A.K.; Fischer, F.R.; Diederich, F. Phosphate recognition in structural biology. Angew. Chem. Int. Ed. Engl. 2007, 46, 338-352. [CrossRef] [PubMed]

13. Wiesner, J.; Borrmann, S.; Jomaa, H. Fosmidomycin for the treatment of malaria. Parasitol. Res. 2003, 90, S71-S76. [CrossRef] [PubMed]

14. Mine, Y.; Kamimura, T.; Nonoyama, S.; Nishida, M.; Goto, S.; Kuwahara, S. In vitro and in vivo antibacterial activities of FR-31564, a new phosphonic acid antibiotic. J. Antibiot. (Tokyo) 1980, 33, 36-43. [CrossRef]

15. Kurz, T.; Geffken, D.; Kaula, U. Organophosphoric Compounds and Use Thereof. Patent WO2005048715-A2, 2 June 2005.

16. Kurz, T.; Schlüter, K.; Kaula, U.; Bergmann, B.; Walter, R.D.; Geffken, D. Synthesis and antimalarial activity of chain substituted pivaloyloxymethyl ester analogues of Fosmidomycin and FR900098. Bioorg. Med. Chem. 2006, 14, 5121-5135. [CrossRef] [PubMed]

17. Haemers, T.; Wiesner, J.; Van Poecke, S.; Goeman, J.; Henschker, D.; Beck, E.; Jomaa, H.; Van Calenbergh, S. Synthesis of alpha-substituted fosmidomycin analogues as highly potent Plasmodium falciparum growth inhibitors. Bioorg. Med. Chem. Lett. 2006, 16, 1888-1891. [CrossRef]

18. Schlüter, K.; Walter, R.D.; Bergmann, B.; Kurz, T. Arylmethyl substituted derivatives of Fosmidomycin: Synthesis and antimalarial activity. Eur. J. Med. Chem. 2006, 41, 1385-1397. [CrossRef]

19. Verbrugghen, T.; Cos, P.; Maes, L.; Van Calenbergh, S. Synthesis and Evaluation of $\alpha$-Halogenated Analogues of 3-(Acetylhydroxyamino)propylphosphonic Acid (FR900098) as Antimalarials. J. Med. Chem. 2010, 53, 5342-5346. [CrossRef]

20. Behrendt, C.T.; Kunfermann, A.; Illarionova, V.; Matheeussen, A.; Pein, M.K.; Gräwert, T.; Kaiser, J.; Bacher, A.; Eisenreich, W.; Illarionov, B.; et al. Reverse Fosmidomycin Derivatives against the Antimalarial Drug Target IspC (Dxr). J. Med. Chem. 2011, 54, 6796-6802. [CrossRef]

21. Woo, Y.H.; Fernandes, R.P.; Proteau, P.J. Evaluation of fosmidomycin analogs as inhibitors of the Synechocystis sp. PCC6803 1-deoxy-D-xylulose 5-phosphate reductoisomerase. Bioorg. Med. Chem. 2006, 14, 2375-2385. [CrossRef] 
22. San Jose, G.; Jackson, E.R.; Haymond, A.; Johny, C.; Edwards, R.L.; Wang, X.; Brothers, R.C.; Edelstein, E.K.; Odom, A.R.; Boshoff, H.I.; et al. Structure-Activity Relationships of the MEPicides: N-Acyl and O-Linked Analogs of FR900098 as Inhibitors of Dxr from Mycobacterium tuberculosis and Yersinia pestis. ACS Infect. Dis. 2016, 2, 923-935. [CrossRef]

23. Fokin, A.A.; Yurchenko, A.G.; Rodionov, V.N.; Gunchenko, P.A.; Yurchenko, R.I.; Reichenberg, A.; Wiesner, J.; Hintz, M.; Jomaa, H.; Schreiner, P.R. Synthesis of the Antimalarial Drug FR900098 Utilizing the Nitroso-Ene Reaction. Org. Lett. 2007, 9, 4379-4382. [CrossRef] [PubMed]

24. Perruchon, J.; Ortmann, R.; Schlitzer, M. A Novel Short and Efficient Synthetic Route to the Antimalarial Agent FR900098 and Derivatives. Synthesis 2007, 2007, 3553-3557.

25. Courtens, C.; Risseeuw, M.; Caljon, G.; Cos, P.; Van Calenbergh, S. Acyloxybenzyl and Alkoxyalkyl Prodrugs of a Fosmidomycin Surrogate as Antimalarial and Antitubercular Agents. ACS Med. Chem. Lett. 2018, 9, 986-989. [CrossRef] [PubMed]

26. Masini, T.; Hirsch, A.K.H. Development of Inhibitors of the 2C-Methyl-d-erythritol 4-Phosphate (MEP) Pathway Enzymes as Potential Anti-Infective Agents. J. Med. Chem. 2014, 57, 9740-9763. [CrossRef] [PubMed]

27. San Jose, G.; Jackson, E.R.; Uh, E.; Johny, C.; Haymond, A.; Lundberg, L.; Pinkham, C.; Kehn-Hall, K.; Boshoff, H.I.; Couch, R.D.; et al. Design of potential bisubstrate inhibitors against Mycobacterium tuberculosis (Mtb) 1-deoxy-d-xylulose 5-phosphate reductoisomerase (Dxr)-Evidence of a novel binding mode. Med. Chem. Comm. 2013, 4, 1099-1104. [CrossRef]

28. Nguyen-Trung, A.T.; Tritsch, D.; Grosdemange-Billiard, C.; Rohmer, M. Synthesis of tetrazole analogues of phosphonohydroxamic acids: An attempt to improve the inhibitory activity against the DXR. Bioorg. Med. Chem. Lett. 2013, 23, 1643-1647. [CrossRef]

29. Edwards, R.L.; Brothers, R.C.; Wang, X.; Maron, M.I.; Ziniel, P.D.; Tsang, P.S.; Kraft, T.E.; Hruz, P.W.; Williamson, K.C.; Dowd, C.S.; et al. MEPicides: Potent antimalarial prodrugs targeting isoprenoid biosynthesis. Sci. Rep. 2017, 7, 8400. [CrossRef]

30. McKenney, E.S.; Sargent, M.; Khan, H.; Uh, E.; Jackson, E.R.; San Jose, G.; Couch, R.D.; Dowd, C.S.; van Hoek, M.L. Lipophilic prodrugs of FR900098 are antimicrobial against Francisella novicida in vivo and in vitro and show GlpT independent efficacy. PLoS ONE 2012, 7, e38167. [CrossRef]

31. Magoulas, G.E.; Tsigkou, T.; Skondra, L.; Lamprou, M.; Tsoukala, P.; Kokkinogouli, V.; Pantazaka, E.; Papaioannou, D.; Athanassopoulos, C.M.; Papadimitriou, E. Synthesis of novel artemisinin dimers with polyamine linkers and evaluation of their potential as anticancer agents. Bioorg. Med. Chem. 2017, 25, 3756-3767. [CrossRef]

32. Capci, A.; Lorion, M.M.; Wang, H.; Simon, N.; Leidenberger, M.; Borges Silva, M.C.; Moreira, D.R.M.; Zhu, Y.; Meng, Y.; Chen, J.Y.; et al. Artemisinin-(Iso)quinoline Hybrids by C-H Activation and Click Chemistry: Combating Multidrug-Resistant Malaria. Angew. Chem. Int. Ed. Engl. 2019, 58, 13066-13079. [CrossRef]

33. Sinha, M.; Dola, V.R.; Agarwal, P.; Srivastava, K.; Haq, W.; Puri, S.K.; Katti, S.B. Antiplasmodial activity of new 4-aminoquinoline derivatives against chloroquine resistant strain. Bioorg. Med. Chem. 2014, 22, 3573-3586. [CrossRef] [PubMed]

34. Miller, M.J.; Walz, A.J.; Zhu, H.; Wu, C.; Moraski, G.; Möllmann, U.; Tristani, E.M.; Crumbliss, A.L.; Ferdig, M.T.; Checkley, L.; et al. Design, Synthesis, and Study of a Mycobactin-Artemisinin Conjugate That Has Selective and Potent Activity against Tuberculosis and Malaria. J. Am. Chem. Soc. 2011, 133, 2076-2079. [CrossRef] [PubMed]

35. Pepe, D.A.; Toumpa, D.; Andre-Barres, C.; Menendez, C.; Mouray, E.; Baltas, M.; Grellier, P.; Papaioannou, D.; Athanassopoulos, C.M. Synthesis of Novel G Factor or Chloroquine-Artemisinin Hybrids and Conjugates with Potent Antiplasmodial Activity. ACS Med. Chem. Lett. 2020, 11, 921-927. [CrossRef] [PubMed]

36. Suresh, S.; Shyamraj, D.; Larhed, M. Synthesis of antimalarial compounds fosmidomycin and FR900098 through N- or P-alkylation reactions. Tetrahedron 2013, 69, 1183-1188. [CrossRef]

37. Uh, E.; Jackson, E.R.; San Jose, G.; Maddox, M.; Lee, R.E.; Lee, R.E.; Boshoff, H.I.; Dowd, C.S. Antibacterial and antitubercular activity of fosmidomycin, FR900098, and their lipophilic analogs. Bioorg. Med. Chem. Lett. 2011, 21, 6973-6976. [CrossRef]

38. Ruiz, J.; Azema, J.; Payrastre, C.; Baltas, M.; Tuccio, B.; Vial, H.; Andre-Barres, C. Antimalarial bicyclic peroxides belonging to the G-factor family: Mechanistic aspects of their formation and iron (II) induced reduction. Curr. Top. Med. Chem. 2014, 14, 1668-1683. [CrossRef] 
39. Stoica, S.; Magoulas, G.E.; Antoniou, A.I.; Suleiman, S.; Cassar, A.; Gatt, L.; Papaioannou, D.; Athanassopoulos, C.M.; Schembri-Wismayer, P. Synthesis of minoxidil conjugates and their evaluation as HL-60 differentiation agents. Bioorg. Med. Chem. Lett. 2016, 26, 1145-1150. [CrossRef]

40. Kumar, M.; Singh, K.; Ngwane, A.H.; Hamzabegovic, F.; Abate, G.; Baker, B.; Wiid, I.; Hoft, D.F.; Ruminski, P.; Chibale, K. Reversed isoniazids: Design, synthesis and evaluation against Mycobacterium tuberculosis. Bioorg. Med. Chem. 2018, 26, 833-844. [CrossRef]

41. Zhao, C.; Jiang, Z.; Mu, R.; Li, Y. A novel sensor for dopamine based on the turn-on fluorescence of Fe-MIL-88 metal-organic frameworks-hydrogen peroxide-o-phenylenediamine system. Talanta 2016, 159, 365-370. [CrossRef]

42. Maroziene, A.; Lesanavicius, M.; Davioud-Charvet, E.; Aliverti, A.; Grellier, P.; Sarlauskas, J.; Cenas, N. Antiplasmodial Activity of Nitroaromatic Compounds: Correlation with Their Reduction Potential and Inhibitory Action on Plasmodium falciparum Glutathione Reductase. Molecules 2019, 24, 4509. [CrossRef]

43. Mwande Maguene, G.; Lekana-Douki, J.-B.; Mouray, E.; Bousquet, T.; Grellier, P.; Pellegrini, S.; Toure Ndouo, F.S.; Lebibi, J.; Pélinski, L. Synthesis and in vitro antiplasmodial activity of ferrocenyl aminoquinoline derivatives. Eur. J. Med. Chem. 2015, 90, 519-525. [CrossRef]

44. Daina, A.; Michielin, O.; Zoete, V. SwissADME: A free web tool to evaluate pharmacokinetics, drug-likeness and medicinal chemistry friendliness of small molecules. Sci. Rep. 2017, 7, 42717. [CrossRef] [PubMed]

45. Trager, W.; Jensen, J. Human malaria parasites in continuous culture. Science 1976, 193, 673-675. [CrossRef]

Sample Availability: Samples of the compounds are available from the authors.

Publisher's Note: MDPI stays neutral with regard to jurisdictional claims in published maps and institutional affiliations.

(C) 2020 by the authors. Licensee MDPI, Basel, Switzerland. This article is an open access article distributed under the terms and conditions of the Creative Commons Attribution (CC BY) license (http://creativecommons.org/licenses/by/4.0/). 